\title{
A selection of eleven plants used as traditional Polynesian cosmetics and their development potential as anti-aging ingredients, hair growth promoters and whitening products
}

\author{
Hughes Kristelle 1, Ho Raimana 1, Butaud Jean-Francois ${ }^{2}$, Filaire Edith ${ }^{3,4}$, Ranouille Edwige ${ }^{3}$, \\ Berthon Jean-Yves ${ }^{3}$, Raharivelomanana Phila ${ }^{1, *}$
}

1 Univ French Polynesia, UMR 241, EIO, BP 6570, F-98702 Tahiti, French Polynesi, France.

2 BP 52832, F-98716 Tahiti, French Polynesi, France.

${ }^{3}$ Greentech SA, Biopole Clermont Limagne, F-63360 St Beauzire, France.

4 Univ Clermont Auvergne, UMR INRA UcA 1019, UNH Human Nutr Unity, ECREIN Team, F-63000

Clermont Ferrand, France.

*Corresponding author : Kristelle Hughes, email address : phila.raharivelomanana@upf.pf

\begin{abstract}
:
Ethnopharmacological relevance: In French Polynesia, embellishment of the hair and skin is an important cultural and everyday practice. Yet, little research has focused on traditional preparations used for beautification in this region and their potential development as innovative cosmetic ingredients.
\end{abstract}

Aim of the study:

In this present study we aim to assess and compile the ethnocosmetic potential of plants of French Polynesia to select and further study plants showing the most promise to be developed as anti-aging, antiblemish and hair care products.

Materials and methods:

A literature analysis of plants of the IECIC list, present in French Polynesia was conducted. The most interesting plants from a cosmetic development standpoint were selected based on four main criteria, i.e. their traditional use in Polynesian cosmetic-related preparations, their biogeographical status, their phytochemistry of cosmetic interest, and lastly their availability and absence from the UICN list. Furthermore, a preliminary screening of antioxidant and anti-inflammatory activities was also performed on several extracts obtained.

Results:

Eleven plants were chosen, and a compilation of multidisciplinary data emphasized each selected plant's potentiality. Traditional allegations showed uses ranging from dermatology such as wound healing or antiinflammatory properties, to hair growth promoting preparations or even skin ligthening ones. Preliminary 
screenings were useful in narrowing the number of extracts to study. Literature-based data associated to traditional uses depicted how the remaining plants and plant parts could be developed for targeted cosmetic applications.

Conclusions:

A prospective approach of plants used traditionally for cosmetic purposes in French Polynesia gave insight on their development potential when paired with the appropriate multidisciplinary data. The eleven plants presented show promise in being developed sustainably as natural anti-aging or hair care products and as skin brightening agents.

\section{Graphical abstract}

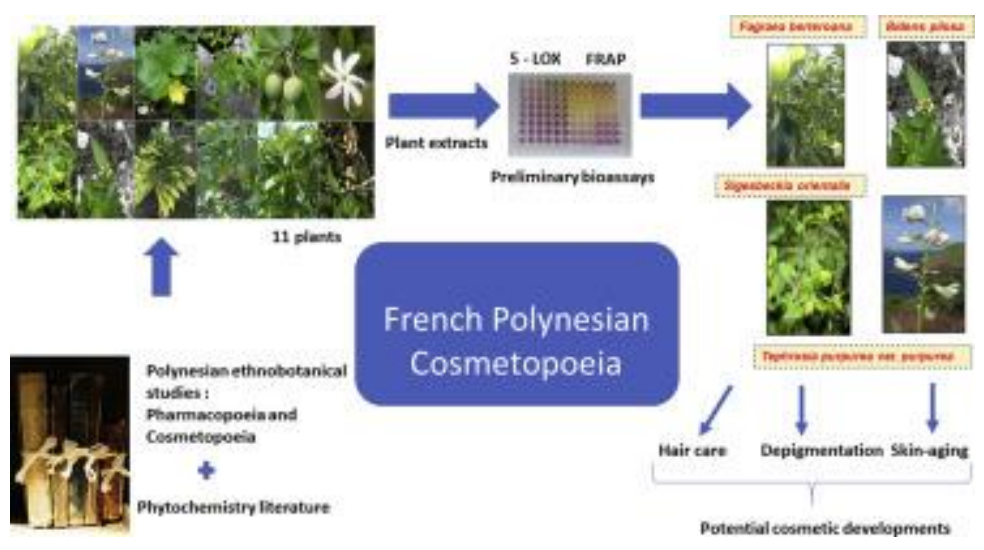

Keywords : Cosmetics, Pharmacopoeia, Polynesia, Inflammation, Antioxidant, Aging, Hair care 


\section{Introduction}

Consumers have growing demands for ethically sound, natural beauty products. This awareness has intensified a shift of cosmetic companies towards developing active compounds that are not only of-natural origin but also respect environmental and ethical norms. In this regard, there has been a renewed enthusiasm in the global cosmetic market to focus on biosourcing and as such, plants, algae, micro-organisms and minerals as source of natural bioactive compounds. In the search for innovative yet effective ingredients, researchers have delved into the ethnobotanical resources of countries worldwide to find plant-based preparations that are used by populations for their beauty and body care (Ahshawat et al., 2008, Pervin et al., 2014, Joshi \& Pawar, 2015). A concept has arisen to better capture this idea: cosmetopoeia.

Cosmetopoeia describes the traditional uses of a plant or a mineral for the embellishment and/or maintenance of the body (Ansel, 2016). In this regard, it is analogous to pharmacopoeia for medicinal plants and purposes. While many countries now possess their own pharmacopoeia, cosmetopoeia remains poorly studied in comparison. Yet, promoting cultural cosmetic knowledge and developing it in a sustainable way, while applying Access and Benefit Sharing requirements, would be a nonnegligible economic opportunity for many countries that possess the cultural knowledge, biomass abundance and floristic originality (Guezennec et al., 2005). French Polynesia has a lot to offer in this respect. It is a French overseas territory part of Eastern Polynesia and is situated in the middle of the 
Pacific Ocean. It is located between $7-28^{\circ} \mathrm{S}$ and $134-155^{\circ} \mathrm{W}$, some $6500 \mathrm{~km}$ away from North America and $6000 \mathrm{~km}$ away from Australia. Polynesians are known for their rich culture in dance, in monoi and in beauty standards (Handy, 1923). Indeed, the image of the vahine, the seductive and beautiful young woman is associated with these Pacific islands (Martin, 2007; Layton, 2015). Embellishment is an inherent part of everyday life as well as a cultural practice. Both men and women use ointments - known as monoi - for their body and hair. Different leaves, barks, wood and flowers are added to coconut oil, namely tiare or Tahitian gardenia (Gardenia taitensis DC.), sandalwood (Santalum insulare Bertero ex A.DC.), Fitchia nutans Hook.f., Sigesbeckia orientalis L., etc. (Girardi et al., 2015; Ansel et al., 2016c) and rubbed or massaged on the skin to perfume, hydrate and protect their hair and skin (Handy, 1923; Whistler, 1985; Pétard, 1986). Naturally, this has stimulated studies on defining cosmetopoeia and some applications in French Polynesia (Ansel et al., $2016 \mathrm{a} / \mathrm{b} / \mathrm{c}$ ). Five groups of traditional cosmetic allegations stemmed from these articles. Dermatology (allegation 1 ) is a cosmetic allegation with a medicinal aspect. Indeed, this category includes claims like wound healing, treating burns, treating eczema, treating abscesses, antiseptic properties, anti-inflammatory, antimicrobial, treating cuts and rashes, astringent and healing or treating any other affections of the dermis and hypodermis. Ulcers were also accounted for as chronic wounds (Agyare, 2016; Jarić, 2018). Action on epidermis (allegation 2), includes all traditional treatments that affect the outmost layer of the skin (its elasticity, its hydration, its general aspect, maintenance and its protection). Pigmentation (allegation 3) incorporates any folk preparations used for skin whitening or inversely bronzing, against blemishes and as skin pigments. "Skin appendages" renamed "hair and nails" (allegation 4) encompasses all traditional uses and preparations concerning hair, hairs and nails, their coloration, care and maintenance. Lastly, "Toiletry" (allegation 5) includes all uses and preparations with properties such as cleansing, for dental hygiene, general hygiene, against sweat, perfume, makeup and invigorating baths as well as closely associated claims (Ansel et al., 2016a). The results from the previous research on the topic led to a cosmetic-oriented ethnobotanical study in the Marquesas Islands (Jost et al., 2016) that sheds light on the cosmetic richness of traditions in Polynesia. These traditional allegations are each linked to modern concepts of skin and hair care.

Our present work aims after this previous prospective as well as applied research, to select and further study plants of French Polynesia with great potential to be developed as anti-ageing, whitening and hair care ingredients. In this effort, a plant selection was conducted starting from the Inventory of Existing Cosmetic Ingredients in China or IECIC 2015 (CFDA, 2015). The plants were selected through literature review of traditional cosmetic allegations such as dermatology and action on epidermis that we linked to anti-ageing, pigmentation related to a whitening application and skin appendages focused on hair growth. Further literature analysis of known biological activities and 
chemical composition of the plants was also necessary to pinpoint the most promising ones. Finally, a preliminary testing of the antioxidant and anti-inflammatory activities of the selected plants was useful in narrowing the number of plants to further our studies on. The compilation of the ethnobotanical data as well phytochemical data of the active plant extracts enabled us to better assess their development potentialities and area of cosmetic application to pursue in.

\section{Materials and Methods}

\subsection{Bibliographical selection}

The data compilation pertaining to traditional uses, biological activities and chemistry of the plants was done using several bibliographical sources, namely ScienceDirect, PubMed, Google scholar, grey literature, books and articles from international and national organizations. Traditional cosmetic uses of interest were those that applied to French Polynesia primarily, the whole Polynesian region and more widely the Pacific region. Asian traditional uses were also included, as various plants present in French Polynesia are originally South-East Asian plants introduced into the Pacific by the ancestors of the Polynesians since their migration across the Pacific Ocean (Christian, 1897; Whistler, 2009).

Several other criteria were examined for our plant selection such as being part of French Polynesia flora and their presence in the IECIC. The IECIC 2015 was used as our primary selection list. This inventory contains over 8,000 cosmetic ingredients with 1,562 plant extracts mentioned. It ensures that the selected plants are more easily marketable as cosmetic ingredients. It also lessens the financial demands and time consumption of proposing a new plant to be included in this authorized list. The Nadeaud database (Florence et al., 2007), with 2,320 taxa listed, was used as the reference list of all plants present in French Polynesia. The comparison between the IECIC 2015 and Nadeaud botanical database led to establish a list of 257 plants' matches (Supplementary material Table S1). These 257 plants of French Polynesia flora were either indigenous, Polynesian introductions or modern introductions. Modern introductions are plants introduced from the $18^{\text {th }}-$ $19^{\text {th }}$ by European settlers till this day (Fourdrigniez \& Meyer, 2008). Polynesian introductions occurred some 1,200 years ago and are plants that were carried and introduced by Polynesians during their voyages across the Pacific (Whistler, 2009). Indigenous species are those that were there prior to Polynesians arrival but are found elsewhere in the world, i.e. are not endemic to French Polynesia. Firstly, we considered the biogeographical status of the plants and their botanical relevance. Indigenous plants and Polynesian introductions were selected. Indeed, indigenous plants are of greater interest in our present aim to select plants from the region, but more so Polynesian introductions. The latter account for useful plants brought by the ancestors of the Polynesians on 
their canoes, whether as dietary [crops] or medicinal plants (Whistler, 2009). Thus, these plants had a high likelihood of being part of the Polynesian pharmacopeia and potentially its cosmetopeia. Modern introductions were not excluded altogether. We included modern introductions well integrated in Polynesian ethnobotany, those having local cultigens of interest, and some invasive plant species that could be controlled by exploitation. Of the initial 257 plants, 41 remained after this first selection. A second processing step consisted in disregarding all modern introductions and Polynesian introductions that are common to many countries' flora and Polynesian introductions with no Polynesian ethnopharmacological uses or specificity. Also, their chemical composition paired to biological activities of cosmetic interest were analyzed. Also, because our approach considers a sustainable development of plants, the availability of the plant material, their conservation status (i.e. threatened or protected species) were also reviewed. Threatened species were naturally excluded from our selection. This led to a finalized list of the most promising ones.

\subsection{Plant collection and extraction}

All plants and plant parts chosen were collected between December 2017 and April 2018 in French Polynesia. Some were collected in the Society Islands and others in the Marquesas Islands. They were identified by the botanist Jean-François Butaud and vouchers were deposited at the herbarium of French Polynesia (PAP).

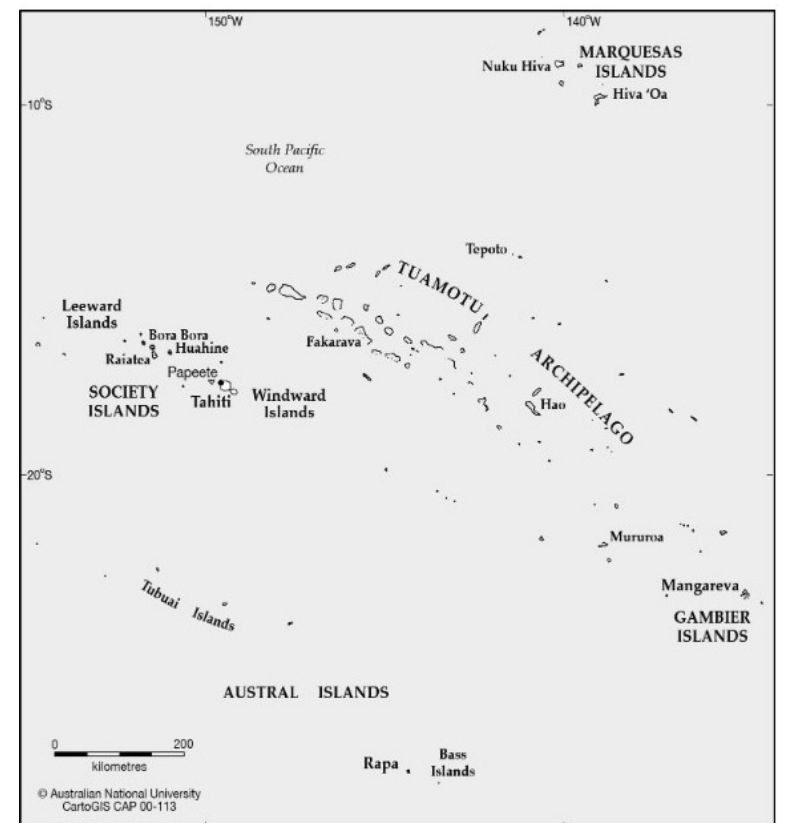

Figure 1 : Map of French Polynesia with the Society Islands in the West and the Marquesas Islands in the North-East

The different parts were oven-dried at $40^{\circ} \mathrm{C}$ then ground to a $2 \mathrm{~mm}$ powder. $A$ third of the powder of each plant part was extracted with $2 \mathrm{~L}$ of ethyl acetate (AcOEt), a third was extracted in $2 \mathrm{~L}$ of ethanol:water (1:1) (EHO) and a third was extracted in $2 \mathrm{~L}$ of water water $\left(\mathrm{H}_{2} \mathrm{O}\right)$. This resulted in three 
extracts of differing polarity per plant part. The extractions were achieved by maceration for 12 hours, under agitation. The dried extracts were obtained after evaporation of volatile solvents and freeze-drying of aqueous extracts. An aliquot of each dried extract was later dissolved in dimethyl sulfoxide to obtain a solution used for the two biochemical screenings.

\subsection{Fluorescence recovery after photobleaching (FRAP)}

In order to evaluate the antioxidant properties of the extracts, an adapted FRAP assay was conducted according to previous papers (Benzie \& Strain, 1996; Adebiyi et al., 2017). Different concentrations of Trolox ranging between $20 \mathrm{mg} \cdot \mathrm{L}^{-1}$ and $1 \mathrm{mg} \cdot \mathrm{L}^{-1}$ were prepared to make a standard curve.

A volume of $50 \mu \mathrm{L}$ of extract or product tested were mixed with $50 \mu \mathrm{L}$ of distilled water in a 96 -well Greiner plate. Then, $200 \mu \mathrm{L}$ of FRAP solution were added and the plate was left to incubate for an hour at $37^{\circ} \mathrm{C}$. The resulting absorbance was read at $593 \mathrm{~nm}$ with a spectrophotometer (TECAN Spark).

The standard curve was plotted:

$\mathrm{DO}=\mathrm{a}^{*}[$ Trolox $]+\mathrm{b}$

The antioxidant activity of the extracts is determined in $\mu \mathrm{mol}$ Trolox equivalent/g of dry matter. All results were obtained in triplicates and the standard deviation (SD) was calculated for each value.

\subsection{5-lipoxygenase assay}

In order to assess the anti-inflammatory activity of the extracts, each was tested in a quartz cuvette. A volume of $2,95 \mathrm{~mL}$ of phosphate buffer at $\mathrm{pH}=9$ was mixed with $30 \mu \mathrm{L}$ of the tested product or extract, $10 \mu \mathrm{L}$ of 5-lipoxygenase at $50000 \mathrm{U} \cdot \mathrm{mL}^{-1}$ and $10 \mu \mathrm{L}$ of either linoleic acid or blank solution for the positive or negative control respectively (Akula \& Odhav, 2008). The absorbance was read at 233 $\mathrm{nm}$ for 60 seconds with 10 seconds intervals on a spectrophotometer U-2001 Hitachi. For each concentration, the 5-lox inhibition percentage was determined as follows

$\%$ inhibition (at a given concentration $)=100\left(\left([\text { O. D sample }]_{t=1 \mathrm{~min}}-[\text { O.D. sample }]_{\mathrm{t}=0 \mathrm{~min}}\right) * 100\right.$ $\left./\left([\mathrm{OD} \text { control }]_{\mathrm{t}=1 \mathrm{~min}}-[\mathrm{O} \text {. D. control }]_{\mathrm{t}=0 \mathrm{~min}}\right)\right)$

The IC50 in \% dry mass is determined using the equation, $y=a x+b$, resulting from the percentage of inhibition as a function of the concentration where IC $50=(50-b) / a$. 


\section{Results and discussion}

\subsection{Plant selection and literature data}

In this present paper, we sought to study whether the Polynesian cosmetopoeia proposed interesting candidates for cosmetic development and what cosmetic applications were most relevant. Few ethnocosmetic studies exist in this region, so our first aim was to select the most interesting plants according to allegations described by Ansel et al. (2016). Upon several screening processes and literature analysis of the initial 257 plants that are explained in Materials and Methods part, we limited our selection to eleven plants that showed interesting ethnocosmetic uses in the Pacific region and accounted for compounds and biological activities relevant in skin and hair care. Table 1 represents a summary of the botanical and collection information of the eleven selected plants, Adenanthera pavonina, Aleurites moluccanus, Bacopa monnieri, Bidens pilosa, Calophyllum inophyllum, Cordyline fruticosa, Fagraea berteroana, Gardenia taitensis, Morinda citrifolia, Sigesbeckia orientalis and Tephrosia purpurea var. purpurea. Amongst these plants, A. pavonina and B. pilosa belong to the modern introductions category and were chosen because they possess interesting traditional cosmetic uses specific to Polynesia (Table 2; Whistler, 2009). The nine remaining plants are either Polynesian introduced ones or indigenous species possessing traditional cosmetic uses of interest for our study. A direct consequence of using the IECIC was that no endemic plants remained in this short list, whereas they account for $60 \%$ of native species (Florence \& Moretti, 2006), the other $40 \%$ being indigenous species. Indeed, little work has been done on endemic plants of French Polynesia for their cosmetic development. Thus, none are listed in any international cosmetic inventory. This observation demonstrates the vast opportunity endemic plants offer for economic development in the cosmetic field. Our lack of endemic plants in this study is not penalizing and remains representative of the plants used as traditional cosmetics in French Polynesia. Indeed, in the Marquesas archipelago, endemic plants account for only $5 \%$ of the plants used in traditional beauty preparations (Jost et al., 2016). They are more present in the overall folk cosmetics of French Polynesia as they make up $27 \%$ of used plants versus $32 \%, 26 \%$ and $15 \%$ for indigenous, modern introduced and Polynesian introduced plants respectively (Butaud, 2013). 
Table 1 : Botanical and collection data of the eleven selected plants from the Society and Marquesan archipelagoes

Plant parts: L (leaves), S (seeds), B (bark), WP (whole plant), F (fruits), FI (flowers), St (Stem) and R (roots). UPF (University of French Polynesia). Local name $T=$ Tahitian and $M=$ Marquesan. Biogeographical status: Mod =

\begin{tabular}{|c|c|c|c|c|c|c|c|c|c|c|c|c|}
\hline $\begin{array}{l}\text { Scientific } \\
\text { name }\end{array}$ & Family & $\begin{array}{l}\text { Voucher } \\
\text { number }\end{array}$ & $\begin{array}{l}\text { Common } \\
\text { name }\end{array}$ & $\begin{array}{l}\text { Local name } \\
(\mathrm{T}) \text { or }(\mathrm{M})^{*}\end{array}$ & $\begin{array}{l}\text { Bioge } \\
\text { ogra- } \\
\text { phical } \\
\text { status }\end{array}$ & $\begin{array}{l}\text { Type of } \\
\text { plant }\end{array}$ & $\begin{array}{l}\text { Plant } \\
\text { part* }\end{array}$ & $\begin{array}{c}\text { Collection } \\
\text { or arrival } \\
\text { date }\end{array}$ & Location & $\begin{array}{c}\text { Island } \\
\text { (Archipelago) }\end{array}$ & $\begin{array}{c}\text { GPS } \\
\text { coordinates }\end{array}$ & $\begin{array}{c}\text { Dry } \\
\text { weight } \\
\text { collected } \\
\text { (g) }\end{array}$ \\
\hline $\begin{array}{l}\text { Adenanthera } \\
\text { pavonina L. }\end{array}$ & $\begin{array}{c}\text { Fabaceae } \\
\text { (Leguminoseae) }\end{array}$ & $\begin{array}{c}\text { K HUGHES } \\
\& T \\
\text { THEOPHILU } \\
\text { S } 1\end{array}$ & Coralwood & $\begin{array}{c}\text { Pitipiti'o } \\
\text { popa'a (T), } \\
\text { Poniu hao'e } \\
\text { (M) }\end{array}$ & Mod & tree & $\mathrm{s}$ & $12 / 11 / 2017$ & UPF & Tahiti (Society) & $\begin{array}{l}17^{\circ} 34.620^{\prime} \mathrm{S} \\
149^{\circ} 36.445^{\prime} \mathrm{W}\end{array}$ & $\begin{array}{r}1560 \\
\text { (fresh) }\end{array}$ \\
\hline $\begin{array}{l}\text { Aleurites } \\
\text { moluccanus } \\
\text { (L.) Willd. }\end{array}$ & & $\begin{array}{c}\text { K HUGHES } \\
\text { \&JF } \\
\text { BUTAUD } 2\end{array}$ & & & & & $\mathrm{~L}$ & & Papehue & & $17^{\circ} 39.602^{\prime} \mathrm{S}$ & 350 \\
\hline $\begin{array}{l}\text { (syn. A. } \\
\text { moluccana) }\end{array}$ & Euphorbiaceae & & $\begin{array}{l}\text { Candelnut } \\
\text { tree }\end{array}$ & $\begin{array}{l}\text { Ti'a'iri (T), } \\
\text { 'Ama (M) }\end{array}$ & Pol & tree & B & $12 / 1 / 2017$ & valley & Tahiti (Society) & $149^{\circ} 34.444^{\prime} \mathrm{W}$ & 1400 \\
\hline $\begin{array}{l}\text { Bacopa } \\
\text { monnieri (L.) } \\
\text { Wettst. }\end{array}$ & $\begin{array}{c}\text { Plantaginaceae } \\
\text { (formerly } \\
\text { Scrophulariacae) }\end{array}$ & $\begin{array}{c}\text { K HUGHES } \\
\text { (leg C } \\
\text { TAATA) } 3\end{array}$ & $\begin{array}{l}\text { Water } \\
\text { hyssop }\end{array}$ & Heiotona (M) & Ind & herb & WP & $12 / 11 / 2017$ & Ho'oumi & $\begin{array}{l}\text { Nuku Hiva } \\
\text { (Marquesas) }\end{array}$ & $\begin{array}{l}08^{\circ} 53.250^{\prime} \mathrm{S} \\
140^{\circ} 01.767^{\prime} \mathrm{W}\end{array}$ & 443 \\
\hline $\begin{array}{l}\text { Bidens pilosa } \\
\text { L. }\end{array}$ & $\begin{array}{c}\text { Asteraceae } \\
\text { (Compositeae) }\end{array}$ & $\begin{array}{c}\text { JF BUTAUD } \\
\& \mathrm{~K} \\
\text { HUGHES } \\
3594\end{array}$ & Black-Jack & Piripiri (T) & Mod & herb & WP & $12 / 9 / 2017$ & $\begin{array}{l}\text { Mount } \\
\text { Marau }\end{array}$ & Tahiti (Society) & $\begin{array}{l}17^{\circ} 35.986^{\prime} \mathrm{S} \\
149^{\circ} 34.222^{\prime} \mathrm{W}\end{array}$ & 1551 \\
\hline & & K HUGHES 8 & & & & & L & $2 / 9 / 2018$ & UPF & Tahiti (Society) & $\begin{array}{l}17^{\circ} 34.645^{\prime} \mathrm{S} \\
149^{\circ} 36.365^{\prime} \mathrm{W}\end{array}$ & 333 \\
\hline $\begin{array}{l}\text { Calophyllum } \\
\text { inophyllum L. }\end{array}$ & Calophyllaceae & & $\begin{array}{l}\text { Alexandrian } \\
\text { laurel }\end{array}$ & $\begin{array}{l}\text { Tamanu (T), } \\
\text { Temanu (M) }\end{array}$ & Pol & tree & $\mathrm{F}$ & $3 / 29 / 2018$ & \multicolumn{3}{|c|}{$\begin{array}{l}\text { Provided by the Laboratoire de Cosmetologie du } \\
\text { Pacific Sud }\end{array}$} & 962 \\
\hline $\begin{array}{l}\text { Cordyline } \\
\text { fruticosa (L.) } \\
\text { A.Chev. (syn. } \\
\text { C. terminalis) }\end{array}$ & $\begin{array}{l}\text { Asparagaceae } \\
\text { (formerly } \\
\text { Agavaceae) }\end{array}$ & $\begin{array}{c}\text { K HUGHES } \\
6\end{array}$ & Cordyline & $\begin{array}{l}\text { ‘Autī or } T(T) \\
\qquad \&(M)\end{array}$ & Pol & shrub & $\mathrm{L}$ & $1 / 15 / 2018$ & Pamatai & Tahiti (Society) & & 222 \\
\hline \multirow{3}{*}{$\begin{array}{l}\text { Fagraea } \\
\text { berteroana } \\
\text { A.Gray ex } \\
\text { Benth. }\end{array}$} & \multirow{3}{*}{$\begin{array}{l}\text { Gentianaceae } \\
\text { (former } \\
\text { Loganiaceae) }\end{array}$} & \multirow[t]{3}{*}{ K HUGHES 4} & \multirow[b]{3}{*}{$\begin{array}{l}\text { Pua keni } \\
\text { keni }\end{array}$} & \multirow[b]{3}{*}{$\begin{array}{c}\text { Pua (T), } \\
\text { Ka'upe (M) }\end{array}$} & \multirow[b]{3}{*}{ Ind } & \multirow[b]{3}{*}{ tree } & B & \multirow[b]{2}{*}{$12 / 9 / 2017$} & \multirow{2}{*}{$\begin{array}{l}\text { Mount } \\
\text { Marau }\end{array}$} & \multirow[b]{3}{*}{$\begin{array}{l}\text { Tahiti (Society) } \\
\text { ) }\end{array}$} & $\begin{array}{l}17^{\circ} 35.840^{\prime} \mathrm{S} \\
149^{\circ} 33.916^{\prime} \mathrm{W}\end{array}$ & 429 \\
\hline & & & & & & & L & & & & $\begin{array}{l}17^{\circ} 35.840^{\prime} \mathrm{S} \\
149^{\circ} 33.916^{\prime} \mathrm{W}\end{array}$ & 1524 \\
\hline & & & & & & & $\mathrm{F}$ & $4 / 26 / 2018$ & UPF & & $\begin{array}{l}17^{\circ} 34.646^{\prime} \mathrm{S} \\
149^{\circ} 36.363^{\prime} \mathrm{W}\end{array}$ & 1350 \\
\hline $\begin{array}{l}\text { Gardenia } \\
\text { taitensis DC. }\end{array}$ & Rubiaceae & $\begin{array}{c}\text { K HUGHES } \\
\text { \& T } \\
\text { LEHARTEL } 7\end{array}$ & $\begin{array}{l}\text { Tahitian } \\
\text { gardenia }\end{array}$ & $\begin{array}{l}\text { Tiare Tahiti } \\
(\mathrm{T}), \text { Tia'e (M) }\end{array}$ & Pol & shrub & $\mathrm{Fl}$ & $1 / 10 / 2018$ & Taravao & Tahiti (Society) & $\begin{array}{l}17^{\circ} 44.147^{\prime} \mathrm{S} \\
149^{\circ} 16.933^{\prime} \mathrm{W}\end{array}$ & 240 \\
\hline $\begin{array}{l}\text { Morinda } \\
\text { citrifolia L. }\end{array}$ & Rubiaceae & K HUGHES 9 & Noni & $\begin{array}{l}\text { Nono (T), } \\
\text { Noni (M) }\end{array}$ & Ind & shrub & L & $2 / 12 / 2018$ & UPF & Tahiti (Society) & $\begin{array}{l}17^{\circ} 34.636^{\prime} \mathrm{S} \\
149^{\circ} 36.501^{\prime} \mathrm{W}\end{array}$ & 354 \\
\hline $\begin{array}{l}\text { Sigesbeckia } \\
\text { orientalis L. }\end{array}$ & $\begin{array}{c}\text { Asteraceae } \\
\text { (Compositeae) }\end{array}$ & $\begin{array}{c}\text { JF BUTAUD } \\
3659\end{array}$ & $\begin{array}{c}\text { Common } \\
\text { St. Paul's } \\
\text { wort }\end{array}$ & $\begin{array}{l}\text { ‘Ami’a (T), } \\
\text { Nio’u (M) }\end{array}$ & Ind. & herb & WP & $3 / 21 / 2018$ & $\begin{array}{l}\text { South of } \\
\text { summit }\end{array}$ & $\begin{array}{l}\text { Me'eti'a } \\
\text { (Society) }\end{array}$ & $\begin{array}{l}17^{\circ} 52.555^{\prime} \mathrm{S} \\
148^{\circ} 04.0483^{\prime} \mathrm{W}\end{array}$ & 22 \\
\hline $\begin{array}{l}\text { Tephrosia } \\
\text { purpurea var. } \\
\text { purpurea (L.) } \\
\text { Pers (syn T. } \\
\text { piscatoria) }\end{array}$ & $\begin{array}{c}\text { Fabaceae } \\
\text { (Leguminoseae) }\end{array}$ & $\begin{array}{l}\text { K HUGHES } \\
\text { (leg J } \\
\text { SIMONNEA } \\
\text { U) } \\
5\end{array}$ & Fishpoison & $\begin{array}{c}\text { Hora (T), } \\
\text { Kohuhu (M) }\end{array}$ & Pol & shrub & L\&St & $12 / 14 / 2017$ & $\begin{array}{l}\text { Plateau } \\
\text { des ânes }\end{array}$ & $\begin{array}{l}\text { Ua Pou } \\
\text { (Marquesas) }\end{array}$ & $\begin{array}{l}09^{\circ} 20.883^{\prime} \mathrm{S} \\
140^{\circ} 04.467^{\prime} \mathrm{W}\end{array}$ & 1129 \\
\hline
\end{tabular}

Modern introduction, Pol = Polynesian introduction and Ind = Indigenous. 
Table 2 presents a literature compilation of the ethnobotanical information gathered on the eleven selected plants while table 3 concentrates on phytochemical data. In order to assess each plant's cosmetic potential, we studied their ethnocosmetic uses in French Polynesia and Polynesia primarily, but also in South-East Asia. The eleven selected plants were classified according to the 5 pre-existing groups of cosmetic allegations (Ansel et al., 2016a).

Table 2 : Traditional cosmetic uses and their corresponding allegations (number in brackets) of the different plant parts in the Pacific-Asian region

\begin{tabular}{|c|c|c|c|}
\hline $\begin{array}{l}\text { Scientific } \\
\text { name }\end{array}$ & $\begin{array}{l}\text { Parts } \\
\text { used }^{+}\end{array}$ & Traditional uses (and reported cosmetic allegation) & References \\
\hline \multirow{2}{*}{$\begin{array}{l}\text { Adenanthera } \\
\text { pavonina }\end{array}$} & S & Crushed seeds used as cataplasms to ripen abscesses (1) & Pétard, 1986 \\
\hline & $\mathrm{B}$ & Solomon Islands: bark used to treat leprosy (1) & WHO, 1998 \\
\hline \multirow[t]{3}{*}{$\begin{array}{l}\text { Aleurites } \\
\text { moluccanus }\end{array}$} & $\begin{array}{l}\text { F } \\
\text { (Nut, } \\
\text { Seeds) }\end{array}$ & $\begin{array}{l}\text { Raw nuts used to cleanse vaginal discharge } \\
\text { Hawaii: oil to treat infants with dry skin, on burns, to prevent stretch marks } \\
\text { during pregnancy, therapeutic massage oil (2), fruits for cuts and purulent } \\
\text { cutaneous infections, ulcers and abscesses (1) } \\
\text { Tonga: chewed nuts used as a soap substituent (5) } \\
\text { Samoa: crushed seeds rubbed unto skin sores, head sores and on skin fungus } \\
\text { called 'utu (1). Chewed preparations also applied to hair to give it an aroma } \\
\text { (5) } \\
\text { Marquesas: green fruits crushed as well as sap for skin diseases such as baby's } \\
\text { thrush } \\
\text { Fiji: the sap of the fruit is used to treat conjunctivitis (1) } \\
\text { Hawaii and Tonga: fruits for scalp (4) }\end{array}$ & $\begin{array}{l}\text { Brown, } 1935 \\
\text { Zepernick, } 1972 \\
\text { Pétard, } 1986 \\
\text { Whistler, 1991, 1992, } 2000 \\
\text { WHO, } 1998\end{array}$ \\
\hline & $\mathrm{B}$ & $\begin{array}{l}\text { Grated bark along with sap to treat coral wounds (1) } \\
\text { Marquesas: bark for cuts (1) and genital hygiene (5) } \\
\text { Fiji: treat gingivitis (1) }\end{array}$ & $\begin{array}{l}\text { Zepernick, } 1972 \\
\text { Pétard, } 1986\end{array}$ \\
\hline & L, St & $\begin{array}{l}\text { Marquesas islands: feminine intimate hygiene (5), lymphatic infections, oral } \\
\text { and thyroidal abscesses (1) and skin diseases (1) } \\
\text { Hawaii: leaves were used as poultice for swellings and infections (1) }\end{array}$ & $\begin{array}{l}\text { Zepernick, } 1972 \\
\text { Krauss, } 1974 \\
\text { Girardi et al., } 2015\end{array}$ \\
\hline $\begin{array}{l}\text { Bacopa } \\
\text { monnieri }\end{array}$ & AP & $\begin{array}{l}\text { Marquesas: medicinal herb (1) } \\
\text { India: used to prevent dandruff and hair loss (4) }\end{array}$ & Brown, 1935 \\
\hline \multirow[t]{2}{*}{ Bidens pilosa } & $\mathrm{L}$ & $\begin{array}{l}\text { Cook Islands: crushed or chewed and used to dress knife wounds (1) } \\
\text { Powder obtained from rubbing the yellow flower between one's fingers is } \\
\text { applied on boils to extract the pus (1) } \\
\text { Philippines: leaves are used to treat boils (1) } \\
\text { Marquesas and Rapa: used as poultice and to dress cuts (1) } \\
\text { Tonga: leaves applied on inflamed eyes (1) }\end{array}$ & $\begin{array}{l}\text { Brown, } 1935 \\
\text { Chopra et al., } 1956 \\
\text { Zepernick, } 1972 \\
\text { Whistler, } 1985\end{array}$ \\
\hline & WP & Marquesas and Rapa: whole as poultice and to dress cuts (1) & $\begin{array}{l}\text { Brown, } 1935 \\
\text { Zepernick, } 1972\end{array}$ \\
\hline $\begin{array}{l}\text { Calophyllum } \\
\text { inophyllum }\end{array}$ & NO & $\begin{array}{l}\text { French Polynesia: eczema and infections, wound healing (1), hair care (4) } \\
\text { Tonga: coconut oil and } C \text {. inophylllum's nut oil mixed to prepare Tongan oil }\end{array}$ & $\begin{array}{l}\text { Krauss, } 1974 \\
\text { Pétard, } 1986\end{array}$ \\
\hline
\end{tabular}




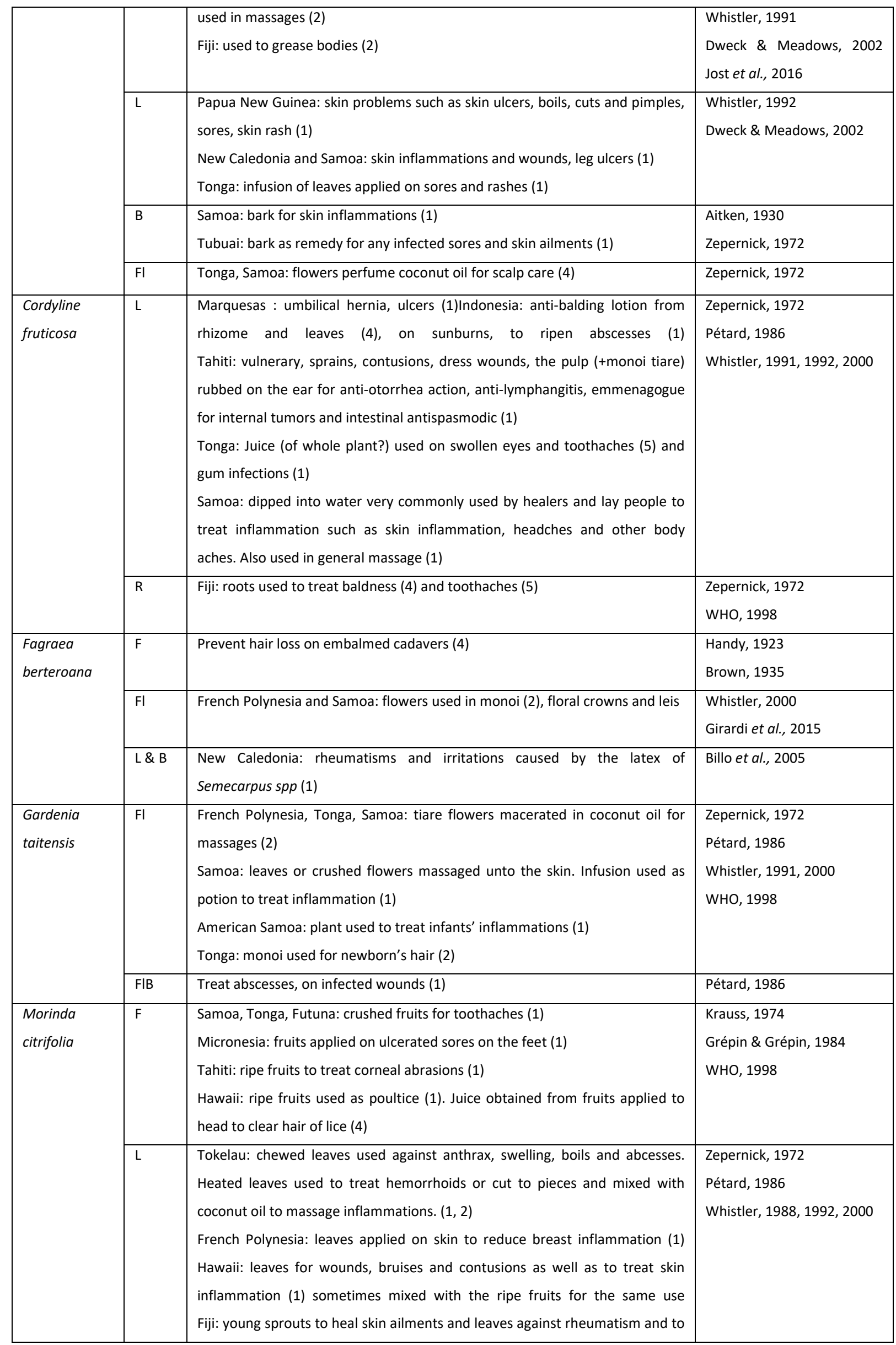




\begin{tabular}{|c|c|c|c|}
\hline & & $\begin{array}{l}\text { treat skin inflammation (1) } \\
\text { Samoa: Leaves or infusion of leaves sometimes massaged unto body aches } \\
\text { and various types of inflammation. The same medicine sometimes used for } \\
\text { boils, infected wounds and swellings (1) } \\
\text { Tonga: leaves applied to boils (1) }\end{array}$ & \\
\hline & $\mathrm{S}$ & Hawaii: seeds and bark for cuts (1) & Zepernick, 1972 \\
\hline & $\mathrm{R}$ & $\begin{array}{l}\text { Hawaii: roots against skin eruptions (1) } \\
\text { New Guinea: roots unto centipede bites. Infusion of root bark to treat skin } \\
\text { diseases and sores on the feet (1) } \\
\text { Cook: infusion of grated roots to treat stone fish stings (1) }\end{array}$ & $\begin{array}{l}\text { Zepernick, } 1972 \\
\text { Whistler, } 1992 \\
\text { WHO, } 1998\end{array}$ \\
\hline & B & Tonga and Fiji: relieve skin inflammation (1) & Zepernick, 1972 \\
\hline & $\mathrm{FI}$ & Tonga and Samoa: petioles and flowers used to treat sties (1) & Whistler, 1992 \\
\hline \multirow[t]{2}{*}{$\begin{array}{l}\text { Sigesbeckia } \\
\text { orientalis }\end{array}$} & $\mathrm{L}, \mathrm{R}$ & $\begin{array}{l}\text { Tahiti: treat wounds and contusions (1), also used in monoi (2) } \\
\text { Leaves are pounded and rubbed on the face for skin whitening ( } 3 \text { ) } \\
\text { New Caledonia: leaves are used to dress wounds (1) } \\
\text { New Guinea: leaves softened from being warmed over a fire are applied to } \\
\text { sores (1) } \\
\text { Tonga: crushed leaves used to treat infants skin ailments (1) }\end{array}$ & $\begin{array}{l}\text { Handy, } 1923 \\
\text { Chopra et al., } 1956 \\
\text { Rageau, } 1973 \\
\text { Pétard, } 1986 \\
\text { Holdsworth et al., } 1989 \\
\text { Whistler, } 1991 \\
\text { Girardi et al., } 2015\end{array}$ \\
\hline & AP & $\begin{array}{l}\text { Samoa: used in scented oil (2) } \\
\text { Cook: treat wounds or skin sores (1) }\end{array}$ & Whistler, 1992, 2000 \\
\hline $\begin{array}{l}\text { Tephrosia } \\
\text { purpurea var. } \\
\text { purpurea }\end{array}$ & $\mathrm{L}$ & $\begin{array}{l}\text { Hawaii: leaves used as lotion for skin ailments, impetigo, ring worms, and } \\
\text { rashes (1) }\end{array}$ & Whistler, 1992 \\
\hline
\end{tabular}

Cosmetic allegations classes 1 to 5 as determined by Ansel et al., (2016a). 1 dermatology, 2 action on epidermis, 3 pigmentation 4 hair and nails and 5 toiletries. ${ }^{+}$Plant parts abbreviations $S=S e e d s, A P=$ Aerial Parts, $W=$ Wood, $R=$ Roots, $B=$ Bark, $L=$ Leaves, $N=$ Nut, St $=$ Stem, $F=$ Fruits, $N O=$ Nut Oil, $S B=$ Stem Bark, $F I=$ Flowers,$C C=$ Cell culture,$F I B=$ Flower bud,$W P=$ Whole plant

We focused on cosmetic applications of interest regarding anti-ageing / well-ageing, antiblemish, hair care, pigmentation and UV-protection as they cover the main cosmetic demands. Thus, the most relevant traditional allegations were allegations 1 and 2 for anti-ageing, allegation 4 for hair care and depigmentation linked to the third allegation. In this study, the main hair-related allegations targeted were promotion of hair growth or prevention of hair loss. The fifth allegation concerning toiletries was not prioritized in our study and was only mentioned for plants within traditional preparations falling in categories 1 through 4 . While toiletry-related uses will briefly be discussed, no cosmetic development will be proposed for the corresponding plant parts.

The eleven plants have dermatology related uses, allegation 1 . The main claims are for wound healing or wound dressing and to treat boils and abscesses (Table 2). Also, an ointment of great importance in the Pacific region is produced from expressing oil from Calophyllum inophyllum kernels. The resulting tamanu oil was used to treat a plethora of skin ailments, but its main property 
remains to heal wounds. Another aspect of dermatology-related preparations cited is plants used as ointments or cataplasms for their anti-inflammatory properties. For example, Morinda citrifolia leaves are used in massages to reduce inflammation, including breast inflammation. Our results, showing that the first allegation is the most cited followed by the second allegation, concur with those of a previous study on cosmetopoeia in tropical regions. This study showed that the main allegations cited for families of lignified plants are the first allegation followed by the second allegation, except in the Arecaceae family, where the order of importance was inverted (Ansel et al., 2016a). Furthermore, the greater number of plants, plant parts and citations in this first category only proves the focus given on pharmacological uses of plants. Indeed, these claims can be included in both pharmacopoeia and cosmetopoeia. As for the second allegation, it is supported by four plants. The nut oil of $A$. moluccanus is used to prevent chapped skin and as therapeutic massage oil. S. orientalis, the flowers of $G$. taitensis and the fruits of $F$. berteroana are each three macerated in coconut oil to prepare distinct monoi. While the main hydration claim is met by the excipient used i.e coconut oil for the plants of the second allegation, the macerated plant organs and their intrinsic properties could bring added benefits and activities to the resulting oils (Ansel et al., 2016c).

Preparations regarding wound-healing, treatment of boils and abscesses, inflammation reduction and skin hydration were of interest for an anti-ageing application. Indeed, the occurrence of abscesses is due to bacterial infection and swelling (Bass, 1975). The latter being a consequence of the activation of inflammation responses. Ultraviolet rays are the most common cause of extrinsic skin aging (Tobin, 2017). Exposure to UV rays leads to inflammation by upregulating the mitogen activated protein kinase MAPK pathway and causing the phosphorylation of c- Jun terminal kinase JNK, factor p38 and Extracellular signal-regulated Kinases 1 \& 2, ERK1/2 in keratinocytes (Carlson et al., 2008; Lei et al., 2017). It also subsequently leads to the release of pro-inflammatory cytokines such as Interleukin-1 (IL-1), IL-6, Tumor Necrosis Factor-alpha (TNF- $\alpha$ ). Both skin-ageing and woundhealing implicate the MAPKinase pathway (Zhao et al., 2017) which explains why we chose to focus on these traditional uses. To summarize, plants having biological activities such as anti-microbial, anti-inflammatory, MAPKinase suppressant were evaluated to determine whether they would be relevant for an anti-aging application. We also reviewed if the plants had effects on collagen, elastin, proteoglycans and metalloproteinases production.

UV exposure also induces pigmentation. During melanogenesis, melanocytes produce melanosomes that contain a pigment called melanin. Melanin is essential to protect the skin against UV radiations and photo-induced carcinogenesis (Berlotto et al., 2001; Costin \& Hearing, 2007; Yamaguchi \& Hearing, 2009, Yamaguchi et al., 2016). They do so through tyrosinase, one of the main targets used in the cosmetic industry to test compounds' lightening (or brightening) activity. 
Tyrosinase iss an enzyme that catalyzes the reaction of substrate L-tyrosinase to L-DOPA further transformed to dopaquinone. The last product will lead to the production of either to pheomelanins, yellow-reddish pigments with the addition of cysteine, or eumelanins, brown-black pigments, in the presence of tyrosinase related proteins 1 and 2, TRP1 and TRP2 (Berlotto et al., 2001). The involvement of keratinocytes in the pigmentation process makes them an interesting cellular target to study, as well as melanocytes, when screening for cellular pigmentation activity of extracts. Indeed, UV radiations stimulate tumor protein p53 in keratinocytes, that bind to the promoter of pro-opiomelanocortin (POMC) and leads to the synthesis of this precursor molecule. POMC cleaves into two hormones, the adrenocortinicotrophic hormone (A-CTH) and the melanocyte stimulating hormone ( $\alpha$-MSH) (Cui et al., 2007; Yamaguchi \& Hearing, 2009). Either A-CTH or $\alpha-M S H$ agonist will bind to melanocyte receptor, M1CR. The activation of M1CR will subsequently lead to stimulation of the microphthalmia-associated transcription factor (MITF) via up-regulation and production of AMPc. MITF stimulates the expression of TRP1, TRP2 and tyrosinase and thus eumelanogenesis, which leads to skin browning or tanning (Berlotto et al., 2001; Yamaguchi \& Hearing, 2009). Our focus is primarily on induced melanogenesis and preventing the appearance of irregular skin tone and dark spots. Sigesbeckia orientalis is the only plant among those retained that is traditionally used for an effect on pigmentation. Indeed, the pounded leaves served as a skin bleaching preparation used by women in the Marquesas Islands (Handy, 1923; Table 2). At this preliminary level, we reviewed if any of the eleven plants produced compounds known to inhibit tyrosinase, to target the proliferation of melanocytes and their dendricity, the transport of eumelanin from melanocytes to keratinocytes or any component of the melanogenesis cascade.

Four plants are used in traditional preparations to prevent hair loss or promote hair growth, B. monnieri, C. inophyllum, C. fruticosa and F. berteroana. A. moluccanus and M. citrifolia have hair related uses for the scalp and to reduce lice respectively. Quite interestingly, both in Indonesia and in Fiji, the roots or rhizomes are used against baldness. In Indonesia, the leaves are also used in the preparation. The choice of plants of interest for their putative hair growth abilities was achieved by pairing traditional uses in the $4^{\text {th }}$ allegation category with literature information supporting such claims, when possible. During normal growth, hair undergo cycling in three phases: anagen or hair follicle formation and elongation phase lasting 2 to 6 years, catagen corresponding to the apoptotic phase of the epithelial cells, hence growth arrest lasting 10 days and telogen characterized by a resting/quiescent phase and finally shedding for 3 months (Sennett \& Rendl, 2012; Oh et al., 2016). Thus, in studying plants capable of preventing hair loss or promoting hair growth, two transition phases are targeted: telogen to anagen and anagen to catagen. The longer the anagen phase, the longer the hair produced. From the telogen to anagen phase, the Bone Morphogenic Protein (BMP) 
pathway is inhibited while the Wnt pathway is activated. Its activation by binding to its Frizzled (Fzl) receptor will inactivate GSK3- $\beta$ through phosphorylation, allowing $\beta$-catenin to accumulate in the cytoplasmic region - as opposed to $\beta$-catenin being ubiquitinated and degraded when the pathway is inactivated. An accumulation of $\beta$-catenin in the cytoplasm will allow it to translocate to the nucleus and activate cell proliferation factors and genes Insulin-like Growth Factor 1 (IGF1), Vascular endothelial growth factor (VEGF), cyclin D1, lef1 in human hair follicle dermal papilla cells HFDPC (Li et al., 2012; Plikus, 2012). This promotes angiogenesis and enables epithelial stem cells to proliferate, divide and begin the process of creating a new hair follicle through DP cells signalling. In comparison, entry into the catagen phase is mediated by several factors including the Fibroblast Growth Factor 5 (FGF5) that binds to Fibroblast Growth Factor Receptor 1, resulting in an inhibition of genes implicated in hair elongation and Dikkopf-1 DKK1 that inhibits Wht pathway and namely Wnt10 (Kwack et al., 2012 Higgins et al., 2014). Herbal compounds able to interfere with pathways or molecules involved in hair cycling, especially in the anagen and catagen phase are already available (Herman \& Herman, 2016). They include targets that alleviate the effects of AGA and AA. Androgenetic alopecia is thought to be caused by a shortening of the anagen phase (Inui \& Itama, 2011). Indeed, androgenetic alopecia is caused by testosterone catalyzed to dihydroxytestosterone (DHT) by type II $5 \alpha$ - reductase. The resulting DHT binds to androgen receptors causing a downregulation of the Wnt pathway and up-regulation of BMP/TGF $\beta$ pathway leading to miniaturization of hair follicle via cell apopotosis, thus shortening the anagen phase and entering and prolonging catagen and later telogen phases (Hibino \& Nishiyama, 2004, Lu et al., 2016). Alopecia areata (AA) is an autoimmune disease that causes hair follicles to attack and destroy themselves. Its precise cause and mechanisms are yet to be discovered. As inflammatory pathways are upregulated in patients suffering from AA, broad inhibitors of the JAK/STAT pathway are used (Han, 2017; Gilhar et al., 2019). At this stage, apart from the traditional use in capillary protection, the chemical composition of the four plants or otherwise explicit biological activity to prevent hair loss were the only means to determine the plant's potential. Any biological activity recorded concerning factors, mechanisms and pathways involved in hair cycling (elongation, arrest, and quiescence) as described above as well as effects resulting in amelioration of AGA were reviewed or searched for.

As for the fifth allegation, the nuts from $A$. moluccanus were used as a soap substituent while the leaves and bark are both used to prepare a cleansing solution for the vagina. This particular use in feminine hygiene is noted for the Marquesas Islands (Table 2). The toiletry allegation from the Marquesas Islands observed in our ethnobotanical data is quite revealing of this specificity. Intimate hygiene whether female or male is an important cultural practice that is more prevalent in the Marquesan archipelago than in other areas of French Polynesia. According to Jost et al. (2016), intimate hygiene is the third category having most citations after skin and hair care as private parts 
are the third most cited application area. During our literature review, many plants had preparations treating genital diseases (gonorrhea, leucorrhea...) with more of a medicinal or healing aspect but a limited number were specific on hygienic uses that cover a cosmetic aspect. Other aspects of toiletries such dental hygiene with toothache cures, and perfume were also found among the 11 reviewed plants.

For the eleven plants, leaves, flowers, fruits and nuts as well as resulting oils are the main constituents of traditional cosmetic-related preparations. They all correspond to renewable plant parts rendering their use less environmentally harmful. Nevertheless, the bark is also used according to several citations, for example A. moluccanus to treat wounds infected by corals (Pétard, 1986) or F. berteroana whose leaves and bark were used against irritations caused by the latex of trees of the Semecarpus species in New Caledonia and Vanuatu (Billo et al., 2005). The roots are also mentioned for Sigesbeckia orientalis (Table 3) or C. fruticosa. Most uses in this study imply one plant part, according to our literature accounts, except for two citations where the bark is associated with another plant part. A. moluccanus bark and sap are used and F. berteroana bark and leaves. In both cases, the application involves the reduction of irritation either directly or indirectly. The involvement of single plants or single plant parts in traditional preparations makes their biological study less challenging as it simplifies the attribution of a detected activity. However, some plant associations are noticeable. The pulp of $C$. fruticosa is mixed with monoi tiare to apply on ear inflammations (otorrhea). The most common mixture remains coconut oil (Girardi et al., 2015; Jost et al., 2016) in which, in our case, fruits or flowers are macerated. Once the plant parts were selected and our activities of interest were defined in accordance with traditional allegations, plant parts of interest were chosen and extracts were screened using various bioassays to identify the most active ones.

Table 3 : Chemical composition and related biological activities of the eleven plants

\begin{tabular}{|c|c|c|c|}
\hline $\begin{array}{l}\text { Scientific } \\
\text { name }\end{array}$ & $\begin{array}{l}\text { Parts } \\
\text { used }^{+}\end{array}$ & Chemical composition & Biological activities \\
\hline \multirow[t]{4}{*}{$\begin{array}{l}\text { Adenanthera } \\
\text { pavonina }\end{array}$} & $\mathrm{S}$ & $\begin{array}{l}\text { Fatty acids such as linoleic, gadoleic, palmitic, lignoceric, oleic, } \\
\text { arachidic and stearic acids (Ezeagu et al., 2004) }\end{array}$ & $\begin{array}{l}\text { Antibacterial (Soares et al., 2014), } \\
\text { anti-inflammatory in vivo (Olajide et } \\
\text { al., 2004), anti-inflammatory on } \\
\text { macrophages (Koodalingam et al., } \\
\text { 2015), antiviral (de Godoi et al., 2014) } \\
\text { antidiabetic (Pandhare et al., 2012) }\end{array}$ \\
\hline & $\mathrm{AP}$ & Pavonin lactone (Ali et al., 2005) & \\
\hline & W & $\begin{array}{l}\text { Flavonoids (robinetin, butein) and flavanonols (ampelopsin or } \\
\text { dihydromyricetin and dihydrorobinetin) (Gennaro et al., 1972) }\end{array}$ & Antioxidant (Gennaro et al., 1972) \\
\hline & $R \& B$ & $\begin{array}{l}\text { Triterpenoids: stigmasterol, methyl oleanolate, methyl } \\
\text { echinocystate, stigmasterol glycoside and acid echinocystic methyl } \\
\text { ester (Yadav et al., 1976; Chandra et al., 1982) }\end{array}$ & $\begin{array}{l}\text { Anti-inflammatory (Mayuren \& } \\
\text { Ilavarasan, 2009) }\end{array}$ \\
\hline
\end{tabular}




\begin{tabular}{|c|c|c|c|}
\hline & $\mathrm{L}$ & 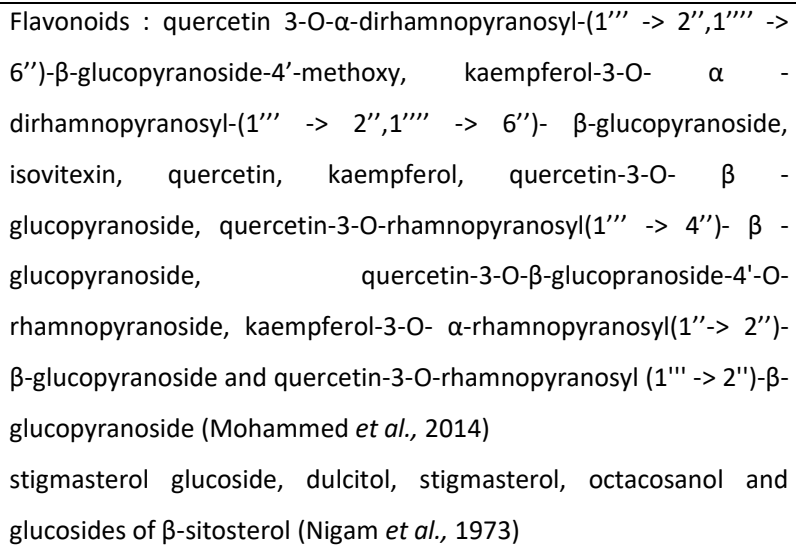 & $\begin{array}{l}\text { Anti-inflammatory (Ara et al., 2010) } \\
\text { Antioxidant (Mohammed et al., 2014; } \\
\text { Wickramaratne et al., 2016) } \\
\text { Anti-quorum sensing (Vasavi et al., } \\
\text { 2015) }\end{array}$ \\
\hline \multirow[t]{3}{*}{$\begin{array}{l}\text { Aleurites } \\
\text { moluccanus }\end{array}$} & $\mathrm{N}$ & $\begin{array}{l}\text { Nut oil: Palmitic, stearic, oleic, linoleic and linolenic acids (Ako et al., } \\
2005 \text { ) }\end{array}$ & $\begin{array}{l}\text { Antioxidant (Athar \& Nasir, 2005; } \\
\text { Siddique et al., 2011) } \\
\text { Anti-rheumatic arthritis (Cock et al., } \\
\text { 2015) }\end{array}$ \\
\hline & B & $\begin{array}{l}\text { 3-acetylaleuritolic acid and scopoletin (Prabowo et al., 2013), } \\
\text { tannins of the mid red bark (Pétard, 1986) and acetylaleuritolic acid } \\
\text { (Meyre-Silva et al., 1997) }\end{array}$ & \\
\hline & L, St & 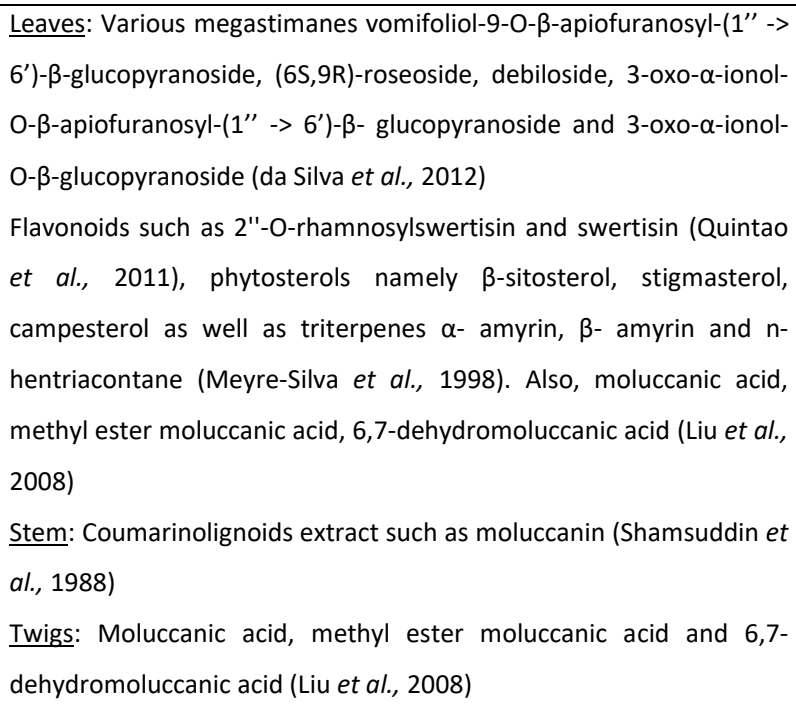 & $\begin{array}{l}\text { Cutaneous anti-inflammatory activity } \\
\text { (Cesca et al., 2012; Hoepers et al., } \\
\text { 2015), antinociceptive (Cesca et al., } \\
\text { 2012; Quintao et al., } 2011 \text { and 2012), } \\
\text { analgesic (Meyre-Silva et al., 1998) } \\
\text { and porcine pancreatic lipase } \\
\text { inhibitor (Ado et al., 2013) }\end{array}$ \\
\hline \multirow[t]{3}{*}{$\begin{array}{l}\text { Bacopa } \\
\text { monnieri }\end{array}$} & $\mathrm{AP}$ & $\begin{array}{l}\text { Bacosterol-3-O- } \beta \text {-D-glucopyranoside, bacopasaponin-C, bacopaside- } \\
\text { I, bacopaside-II, bacosterol, bacosine and luteolin-7-O-b - } \\
\text { glucopyranoside (Bhandari et al., 2007) }\end{array}$ & $\begin{array}{l}\text { Wound healing (Sharath et al., 2010), } \\
\text { anti-inflammatory for the nervous } \\
\text { system (Nemetcheck et al., 2017) }\end{array}$ \\
\hline & WP & $\begin{array}{l}\text { p-hydroxyl benzenemethanol, p-hydroxyl benzoic acid, 5,24(28)- } \\
\text { ergostadien-3 } \beta \text {-ol, ursolic acid, lupeol, } 28 \text {-hydroxyllupeol, } \\
\text { stigmasterol-3-O- } \beta \text {-D-glucopyranoside, } \\
\text { ampelozigenin, 3,4-dimethoxycinnamic acid, feruloyl glucoside, } \\
\text { rosavin, quercetin, apigenin, luteolin, zizyotin, loliolide, bacopasides } \\
\text { VI-VIII, bacopasides I \& II and bacopasaponin (Zhou et al., 2007) }\end{array}$ & $\begin{array}{l}\text { Herbal formulation as hair growth } \\
\text { stimulant (Banerjee et al., 2009) }\end{array}$ \\
\hline & $\mathrm{L}$ & $\begin{array}{l}\text { Triterpenes saponosides derivatives of jujubogenine and } \\
\text { pseudojujubogenine of the methanolic extract, bacopasaponins E } \\
\text { and F, bacopasides I- V, bacopasaponine C, bacopasides N1 and N2, } \\
\text { bacopaside X, bacoside A3 (Sivaramakrishna et al., 2005) } \\
\text { bacopasaponins A-C (Garai et al., 1996) }\end{array}$ & \\
\hline
\end{tabular}




\begin{tabular}{|c|c|c|c|}
\hline \multirow[t]{3}{*}{ Bidens pilosa } & $L$ & $\begin{array}{l}\text { Sesquiterpenes and polyacetylenes E-caryophyllene, } \beta \text {-gurjunene, } \alpha \text { - } \\
\text { humulene, germacrene-D, biciclogermacrene, } \alpha \text {-muurolene, Z- }- \text { - } \\
\text { bisabolene, selina-3,7(11)-diene (Grombone-Guaratini et al., 2005) } \\
\text { Stigmasterol, squalene, elaidic and behenic acids, and phytyl } \\
\text { heptanoate (Zulueta et al., 1995) } \\
\text { Several volatile compounds were found in the hydrodistillate, some } \\
\text { being } 1 \text {-phenyl hepta-1,3,5-triyne, } \alpha \text {-pinene, limonene, p- } \\
\text { caryophyllene, germacrene-D, } \beta \text {-copaene, } \beta \text {-cyclogermacrene, } \\
\text { linalol, } \alpha \text {-cadinol (Zollo et al., 1995) }\end{array}$ & \\
\hline & $\mathrm{AP}$ & 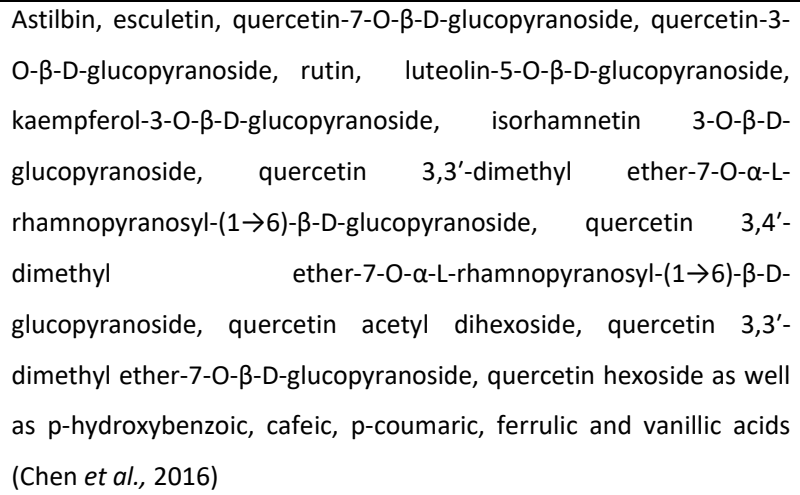 & $\begin{array}{l}\text { Cyclooxygenase and PGE2 inhbitor } \\
\text { (Yoshida, 2006) } \\
\text { Antioxidant: ROS inhibition and NO } \\
\text { activation in dermal endothelial cells } \\
\text { (Kohda et al., 2013) } \\
\text { antimicrobial (Geissberger \& Séquin, } \\
\text { 1991) }\end{array}$ \\
\hline & WP & $\begin{array}{l}\text { Phenolic compounds heptanyl 2-O- } \beta \text {-xylofuranosyl-(1-6)- } \beta \text { - } \\
\text { glucopyranoside, quercetin 3-Orabinobioside, quercetin 3-O- } \\
\text { rutinoside, jacein, centaurein, chlorogenic acid, 3,4-di-O- } \\
\text { caffeoylquinic acid, 3,5-di-O-caffeoylquinic acid and 4,5-di-O- } \\
\text { caffeoylquinic acid (Chiang et al., 2004) } \\
\text { Centaurein and centaureidin (Chang et al., 2007) } \\
\text { Flavonoids and other compounds such as linolic et } \alpha \text {-linolenic acids, } \\
\text { squalene, friedelin, friedelan-3- } \beta \text {-ol, stigmasterol, } \beta \text {-sitosterol, } \\
\text { campestrol, luteolin 7-O- } \beta \text {-D-glucopyranoside, quercetin 3-O- } \beta \text {-D- } \\
\text { glucopyranoside, quercetin 3-O- } \beta \text {-D-galactopyranoside and } \\
\text { quercetin 3-O- } \beta \text {-D-glucuronopyranoside (Geissberger \& Sequin, } \\
\text { 1991) } \\
\text { Rutin, hyperoside, and 4,5-O-dicaffeoylquinic acid (Cortés-Rojas et } \\
\text { al., 2013) }\end{array}$ & $\begin{array}{l}\text { Antioxidant: DPPH, anti-radical and } \\
\text { NO inhibitor (Chiang et al., 2004; } \\
\text { Cortés-Rojas et al., 2013) } \\
\text { immunomodulatory (Chang et al., } \\
\text { 2007) } \\
\text { anti-aging activity of phytol } \\
\text { (Dieamant et al., 2015). }\end{array}$ \\
\hline \multirow[t]{2}{*}{$\begin{array}{l}\text { Calophyllum } \\
\text { inophyllum }\end{array}$} & NO & $\begin{array}{l}\text { Fatty acids such as palmitic acid, palmitoleic acid, stearic acid, oleic } \\
\text { acid, linoleic acid, alpha-linoleic, arachidonic acid, alpha-gadoleic, } \\
\text { dihomo-gamma-linolenic acid, behenic acid, docosadienoic acid } \\
\text { (Adewuyi et al., 2014; Raharivelomanana et al., 2018) } \\
\text { Flavanoids such as tamanolides D and P, inophyllum C, D, E and P as } \\
\text { well as calanolides A, B, Gut } 70 \text { and P (Ansel et al., 2016) } \\
\text { Inophyllum A, C and E as well as calophylloide, calophynic acid, } \\
\text { 11,12-anhydroinophyllum,1,7-dihydroxy-6-methoxyxanthone, n- } \\
\text { nonacosane and sitosterol-3-O-D-glucopyranoside (Zakaria et al., } \\
\text { 2014) }\end{array}$ & $\begin{array}{l}\text { Antibacterial (Adewuyi et al., 2014; } \\
\text { Léguillier et al., 2015) } \\
\text { Antiacneic (Léguillier et al., 2015) } \\
\text { Wound healing (Léguillier et al., 2015; } \\
\text { Ansel et al., 2016b) } \\
\text { Anti-inflammatory and wound- } \\
\text { healing calophyllolides (Nguyen et al., } \\
\text { 2017) } \\
\text { Anti-inflammatory (Perumal et al., } \\
\text { 2017) }\end{array}$ \\
\hline & $\mathrm{L}$ & $\begin{array}{l}\text { Coumarins such as calophyllolide, inophyllums B, C, G1, G2 and P (-)- } \\
\text { 12-methoxyinophyllum } A,(+)-12 \text {-methoxyinophyllum } \mathrm{H}-1,(-)\end{array}$ & $\begin{array}{l}\text { Antimicrobial activity (Ali et al., 1999) } \\
\text { Antitumoral activity against HL-60 }\end{array}$ \\
\hline
\end{tabular}




\begin{tabular}{|c|c|c|c|}
\hline & & $\begin{array}{l}\text {-12-methoxyinophyllum H-2, and inophyllum J, 12-ethoxyino- } \\
\text { phyllum D and isoinophynone (Laure et al., 2008; Li et al., 2016) } \\
\text { Triterpenoids: 33,23-epoxy-friedelan-28-oic acid, epifriedelanol, } \\
\text { canophyllal, oleanolic acid friedelin, inophynone, canophyllol and } \\
\text { canophyllic acid (Ali et al., 1999; Li et al., 2010; Prasad et al., 2012) } \\
\text { Amentoflavone (Prasad et al., 2012) } \\
\text { (2S,3R)-2,3-dihydro-5-hydroxy-2,3,8,8-tetramethyl-6-(I- } \\
\text { phenylethenyl)-4H,SHbenzo[1,2-b:3,4-b'] dipyran-4-one and (2R,3R)- } \\
\text { Benzodipyranone: 2,3-dihydro-5-hydroxy-2,3,8,8-tetramethyl-6-(1- } \\
\text { phenylethenyl)-4H,8H-benzo [1,2-b:3,4-b'] dipyran-4-one (Khan et } \\
\text { al., 1996) } \\
\text { Aerial parts: Phenylcoumarins such as Inophyllum-A, C, D and E, } \\
\text { calocoumarin-A, calophyllolide, apetatolide, calocoumarin-B, } \\
\text { calocoumarin-C, isocalophyllic acid (Itoigawa et al., 2001) }\end{array}$ & $\begin{array}{l}\text { cells (Li et al., 2010) and Epstein-Barr } \\
\text { virus early antigen suppressing } \\
\text { activity (Itoigawa et al., 2001) } \\
\text { Antidyslipidemic activity (Prasad et } \\
\text { al., 2012) } \\
\text { Anti-inflammatory (Tsai et al., 2012) }\end{array}$ \\
\hline & SB & $\begin{array}{l}\text { friedelin and betulinic acid, inophinnin, inophyllin A, caloxanthone } \\
\text { C, pyranojacareubin and stigmasterol and 4-hydroxyxanthone (Ee et } \\
\text { al., 2011) nophinnin, inophinone, pyranojacareubin, } \\
\text { rheediaxanthone A, macluraxanthone, 4-hydroxyxanthone (Mah et } \\
\text { al., 2015) }\end{array}$ & $\begin{array}{l}\text { Inophinnin, mild anti-inflammatory } \\
\text { (Ee et al., 2011) } \\
\text { Anti-arthritic (Perumal et al., 2017) }\end{array}$ \\
\hline $\begin{array}{l}\text { Cordyline } \\
\text { fruticosa }\end{array}$ & $\mathrm{L}$ & 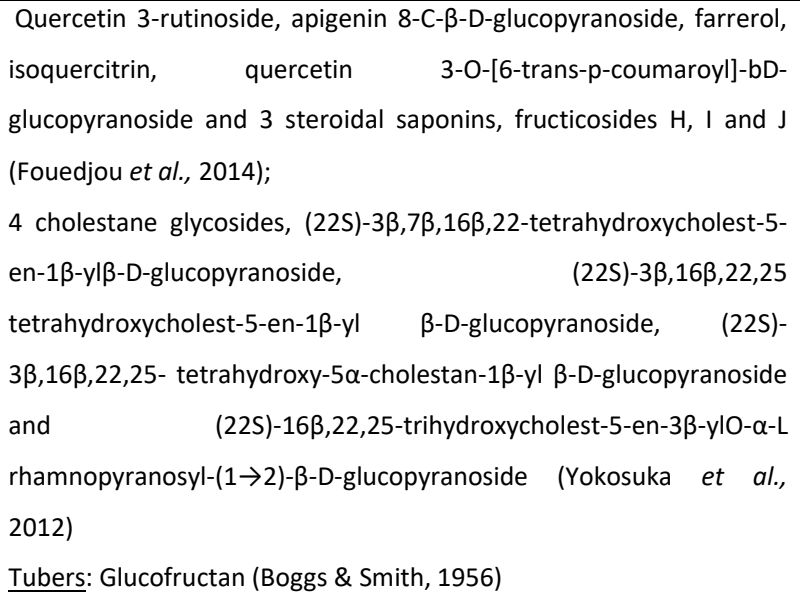 & Antimicrobial (Fouedjou et al., 2014) \\
\hline \multirow[t]{3}{*}{$\begin{array}{l}\text { Fagraea } \\
\text { berteroana }\end{array}$} & $\mathrm{F}$ & $\begin{array}{l}\text { Fruits: monoterpenes alkaloids (Kun-Anake \& Ragvatin, 1976) ursolic } \\
\text { and oleanolic acids (Basir et al., 2018) } \\
\text { Roots: lignans (Okuyama et al., 1995) }\end{array}$ & \\
\hline & $\mathrm{FI}$ & $\begin{array}{l}\text { Benzyl acetate, methyl benzoate, benzylbenzoate, (E)- } \beta \text {-ocimene, } \\
\text { methyl salicylate, benzyl salicylate, acetoin, acetic acid, nerolidol, } \\
\text { henicosane, tricosane and myristic acid (Hayashi, 1995) }\end{array}$ & \\
\hline & $L \& B$ & $\begin{array}{l}\text { Wood and bark: iridoids, coumaric and caffeic acids (Cambie et al., } \\
\text { 1990), di-O-methylcrenatin, potalioside B, adoxosidic acid, } \\
\text { adoxoside, (b)-pinoresinol, salicifoliol, sweroside, taxifolin-6-C- } \\
\text { glucoside, aromadendrin-6-C-glucoside, secologanoside, loganic acid } \\
\text { (Suciati et al., 2011) } \\
\text { Leaves: flavonoids (Qasim et al., 1987), monoterpenes alcaloids } \\
\text { (Kun-Anake \& Ragvatin, 1976) and blumeosides A-D (Cuendet et al., } \\
\text { 1997) }\end{array}$ & \\
\hline Gardenia & FIB & Over 150 volatile compounds such as linalool, dihydroconiferylic & \\
\hline
\end{tabular}




\begin{tabular}{|c|c|c|c|}
\hline taitensis & & $\begin{array}{l}\text { alcohol, 2-methoxy-4-vinyl-phenol, isoeugenol, benzyles benzoate } \\
\text { and salicylate, dihydroconiferyl acetate, benzoate and salicylate, } \\
\text { ethyl hexanoate, geranyl benzoate, (Z)-3-hexenyl benzoate and } \\
\text { salicylate, hexyl benzoate, methyl salicylate, 2-phenylethyl benzoate } \\
\text { and salicylate, phenylacetonitrile, phenylacetaldoxime and 2- } \\
\text { phenylnitroethane (Claude-Lafontaine et al., 1992) } \\
\text { Four triterpenes namely 9,19-cyclolanostane-3,23-dione (Davies et } \\
\text { al., 1992) } \\
\text { Flavonoid: 6-methoxy-3-O-methylkaempherol (Miller et al., 1989) }\end{array}$ & \\
\hline \multirow[t]{4}{*}{$\begin{array}{l}\text { Morinda } \\
\text { citrifolia }\end{array}$} & $\mathrm{CC}$ & $\begin{array}{l}\text { 2-methyl-3,5,6-trihydroxyanthraquinone, 3-hydroxymorindone, 5,6- } \\
\text { dihydroxylucidin, } \quad \text {-methyl-3,5,6-trihydroxyanthraquinone-6- } \beta \text { - } \\
\text { primeveroside, 3-hydroxymorindone-6- } \beta \text {-primeveroside, 5,6- } \\
\text { dihydroxylucidin-3- } \beta \text {-primeveroside, rubiadin, lucidin, morindone, } \\
\text { lucidin-3- } \beta \text {-primeveroside and morindone-6- } \beta \text {-primeveroside (Inoue } \\
\text { et al., 1981) }\end{array}$ & $\begin{array}{l}\text { Roots: analgesic (Younos et al., 1990); } \\
\text { antioxidant (Zin et al., 2002) }\end{array}$ \\
\hline & $\mathrm{F}$ & $\begin{array}{l}51 \text { volatiles compounds including 3-methyl-3-buten-1-ol and the } \\
\text { octanoic, hexanoic and decanoic acids (Farine et al., 1996) } \\
\text { 6-O-( } \beta \text {-D-glucopyranosyl)-1-O-octanoyl- } \beta \text {-D-glucopyranose, 6-O-( } \beta \text { - } \\
\text { D-glucopyranosyl)-1-O-hexanoyl- } \beta \text {-D-glucopyranose and } \\
\text { methylbut-3-enyl } \quad \text { 6-O- } \beta \text {-D-glucopyranosyl- } \beta \text {-D-glucopyranoside } \\
\text { (Wang et al., 2000), 2,6-di-O-( } \beta \text {-D-glucopyranosyl)-1-O-octanoyl- } \beta \text {-D- } \\
\text { glucopyranose, rutin and asperulosidic acid (Wang et al., 1999), } \\
\text { 5,15-dimethylmorindol, morindacin as well as other anthraquinones } \\
\text { and iridoids Kamiya et al., 2005) }\end{array}$ & $\begin{array}{l}\text { Anti-inflammatory activity of the } \\
\text { fruits (Akihisa et al., 2007) and juice } \\
\text { (McKoy et al., 2002). Antitumoral } \\
\text { (Hirasumi \& Furusawa et al., 1999; Liu } \\
\text { et al., 2001) and antioxidant activities } \\
\text { (Ramamoorthy \& Bono, 2007; Zin et } \\
\text { al., 2002), }\end{array}$ \\
\hline & $\mathrm{L}$ & 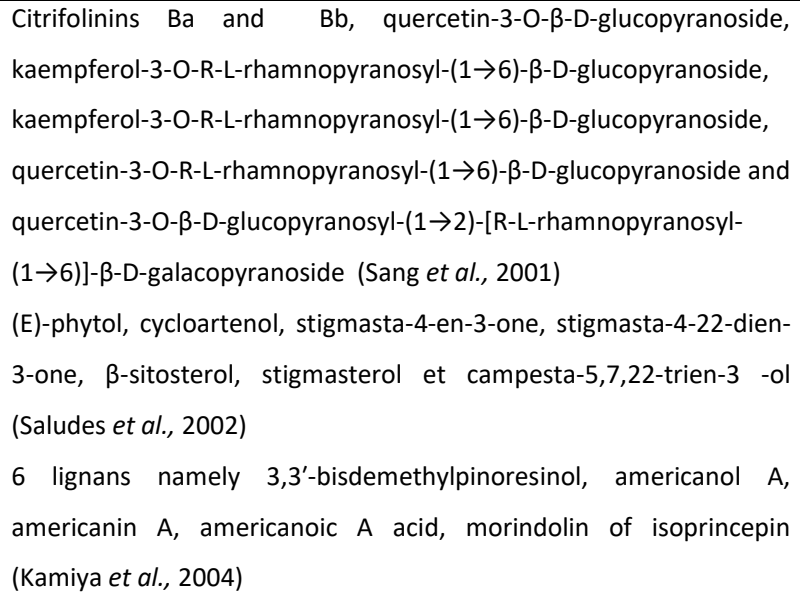 & $\begin{array}{l}\text { Wound healing (Nayak et al., 2009), } \\
\text { antiartherosclerosis (Kamiya et al., } \\
\text { 2004), antitubercular (Saludes et al., } \\
\text { 2002) and antioxidant (Sang et al., } \\
\text { 2001; Zin et al., 2002) }\end{array}$ \\
\hline & $S$ & $\begin{array}{l}\text { ursolic acid, americanin A, 3,3'-bisdemethylpinoresinol and } \\
\text { quercetin (Masuda et al., 2009) }\end{array}$ & $\begin{array}{l}\text { Anti-tyrosinase and anti-elastase } \\
\text { (Masuda et al., 2009) }\end{array}$ \\
\hline $\begin{array}{l}\text { Sigesbeckia } \\
\text { orientalis }\end{array}$ & $\begin{array}{l}\text { L, R, } \\
\text { AP }\end{array}$ & 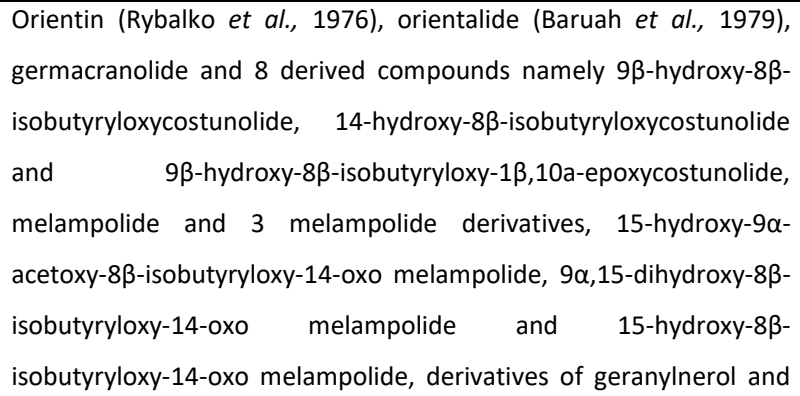 & $\begin{array}{l}\text { Anticancer (Chang et al., 2014), anti- } \\
\text { inflammatory (Hwang et al., 2001; } \\
\text { Wang et al., 2011; Hong et al., 2014) } \\
\text { and immunosuppressive (Sun et al., } \\
\text { 2006) }\end{array}$ \\
\hline
\end{tabular}




\begin{tabular}{|c|c|c|c|}
\hline & & 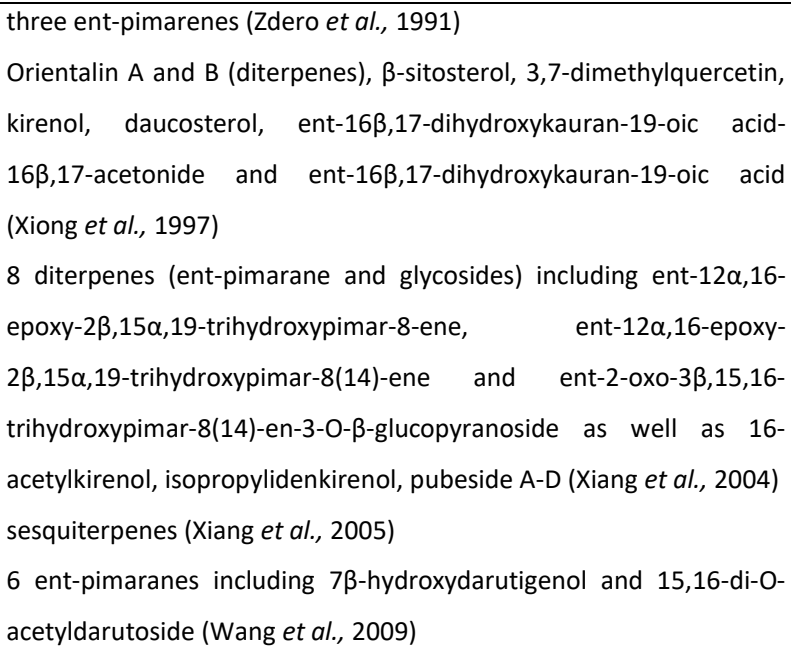 & \\
\hline \multirow{4}{*}{$\begin{array}{l}\text { Tephrosia } \\
\text { purpurea var. } \\
\text { purpurea }\end{array}$} & WP & Rutin and quercetin (Bhadada et al., 2016) & \\
\hline & St & $\begin{array}{l}\text { Flavones: lanceolatins A and B, semiglabrin and terpurinflavone } \\
\text { (Juma et al., 2011) }\end{array}$ & \\
\hline & $\mathrm{L}$ & $\begin{array}{l}\text { 2-propenoic acid, 3-(4-(acetyloxy)-3-methoxypheny)-3(4-actyloxy)-3- } \\
\text { methoxyphenyl)-2-propenyl ester, } \quad \text { 4-isopropyl-1,8-dimethyl- } \\
\text { decahydro-azulene-5,8,9-triol and apollinin (Kalafalah et al., 2010) }\end{array}$ & \\
\hline & AP & $\begin{array}{l}\text { Flavonoids: tephropurpulin A, isoglabratephrin and glabratephrin } \\
\text { (Hegazy et al., 2009) } \\
\text { tephrosin, pongaglabol et semiglabrin (Ahmad et al., 1999) }\end{array}$ & Wound healing (Lodhi et al., 2006) \\
\hline
\end{tabular}

+ Plant parts abbreviations $S=$ Seeds, $A P=$ Aerial Parts, $W=$ Wood, $R=$ Roots, $B=$ Bark, $L=$ Leaves, $N=N u t$, St $=$ Stem, $F=$ Fruits, $N O=$ Nut Oil, $S B=$ Stem Bark, $F I=$ Flowers,$C C=$ Cell culture,$F I B=$ Flower bud,$W P=$ Whole plant

\subsection{Bioassay results}

\subsubsection{Choice of plant parts and extraction}

The plant parts chosen for further extraction were those that had traditional uses as specified in Table 2. For herbs, such as B. monnieri and B. pilosa (table 1), the whole plant was extracted. Traditional uses for the leaves and whole B. pilosa plant are similar, so the whole plant was chosen. As for B. monnieri, aerial parts are mentioned in table 2 , but according to table 3 , the whole plant is used in an herbal formulation for hair growth, this supports the use of the whole plant for extraction. Renewable plant parts were focused on unless the whole plant was provided, such is the case for T. purpurea although only the leaves are reported as having traditional uses. In the case of $A$. moluccanus and $F$. berteroana, the barks were also available and enabled their study. Flowers were not studied if their noted ethnocosmetic use was to perfume coconut oil. This corresponds to allegation 5 , that is not being studied, as precised above.

Furthermore, each selected plant part led to three extracts, an ethyl acetate extract, an ethanol: water extract and a water extract. Nevertheless, some extracts yielded a too small amount 
to carry out the preliminary assays $(<20 \mathrm{mg}$ ) (Supplementary data List S2). The list of 32 extracts in sufficient quantity is given with their yield and mass in Table 4.

\subsubsection{FRAP and 5-LOX results}

After the plant collection and extraction steps, 32 finalized extracts were obtained and tested on the FRAP test. The FRAP test was used to measure the antioxidant potential of all the extracts obtained while the 5-LOX assay was tested on plant parts having a traditional use implying their antiinflammatory potential. These two preliminary tests were conducted in order to select the most active extracts and pursue relevant in cellulo tests in accordance with their targeted cosmetic development axes.

In our antioxidant assay (Table 4), the best antioxidant activities are displayed by the ethyl acetate extracts of $A$. moluccanus bark, $B$. pilosa the whole plant, the leaves of $C$. inophyllum and the bark of $T$. purpurea var. purpurea as well as $C$. inophyllum leaves aqueous extract. Their activities are $1331.58 \pm 24.18,1123.61 \pm 83.11,1683.04 \pm 138.68,1262.49 \pm 24.03$ and $1044.40 \pm 58.40 \mu \mathrm{mol}$ Trolox equivalent/g of dry matter respectively. Comparatively, some plant parts showed very low antioxidant activity such as $A$. pavonina seeds ethyl acetate extract with $38.71 \pm 7.19 \mu \mathrm{mol}$ Trolox equivalent/g. The best faring extracts are considered mild antioxidant. Indeed, our standard, a green tea extract has very strong antioxidant potential and a value of $15348.23 \pm 521.02 \mu \mathrm{mol}$ Trolox equivalent/g of dry matter.

Table 4 : Antioxidant potential of the 32 tested extracts

\begin{tabular}{|c|c|c|c|c|c|c|}
\hline Plant species & Plant part & $\begin{array}{l}\text { Extraction } \\
\text { solvent }^{1}\end{array}$ & $\begin{array}{l}\text { Extract dry } \\
\text { mass (g) }\end{array}$ & Yield (\%) & $\begin{array}{l}\text { Trolox equivalent } \\
(\mu \mathrm{mol} / \mathrm{g} \text { of } \mathrm{DM})\end{array}$ & SD \\
\hline A. pavonina & Seeds & EtOAc & 41.22 & 13.74 & 38.71 & 7.19 \\
\hline \multirow[t]{4}{*}{ A. moluccanus } & \multirow[t]{2}{*}{ leaves } & $\mathrm{EHO}$ & 3.66 & 3.14 & 134.76 & 35.15 \\
\hline & & $\mathrm{H} 2 \mathrm{O}$ & 1.69 & 1.45 & 253.72 & 18.68 \\
\hline & \multirow[t]{2}{*}{ bark } & EtOAc & 0.51 & 0.11 & 1331.58 & 24.18 \\
\hline & & $\mathrm{EHO}$ & 3.66 & 0.69 & 225.45 & 91.69 \\
\hline \multirow[t]{3}{*}{ B. monnieri } & \multirow[t]{3}{*}{ whole plant } & EtOAc & 4.44 & 3.01 & 127.15 & 9.95 \\
\hline & & $\mathrm{EHO}$ & 4.35 & 2.95 & 216.23 & 6.94 \\
\hline & & $\mathrm{H} 2 \mathrm{O}$ & 9.78 & 6.63 & 305.36 & 36.02 \\
\hline \multirow[t]{3}{*}{ B. pilosa } & \multirow[t]{3}{*}{ whole plant } & EtOAc & 0.99 & 0.20 & 1123.61 & 83.11 \\
\hline & & $\mathrm{EHO}$ & 16.78 & 3.36 & 711.05 & 46.59 \\
\hline & & $\mathrm{H} 2 \mathrm{O}$ & 8.80 & 1.76 & 253.38 & 84.93 \\
\hline \multirow[t]{2}{*}{ C. inophyllum } & \multirow[t]{2}{*}{ leaves } & EtOAc & 5.92 & 5.33 & 1683.04 & 138.69 \\
\hline & & $\mathrm{H} 2 \mathrm{O}$ & 6.44 & 5.8 & 1262.5 & 24.03 \\
\hline
\end{tabular}




\begin{tabular}{|c|c|c|c|c|c|c|}
\hline & \multirow[t]{4}{*}{ fruits } & EtOAc & 81.65 & 34.02 & 159.62 & 18.90 \\
\hline & & EHO & 24.77 & 10.32 & 309.53 & 25.94 \\
\hline & & EtOH & 28.74 & 11.98 & 562.81 & 43.45 \\
\hline & & $\mathrm{H} 2 \mathrm{O}$ & 1.83 & 0.76 & 338.13 & 161.38 \\
\hline \multirow[t]{2}{*}{ C. fruticosa } & \multirow[t]{2}{*}{ leaves } & EHO & 4.32 & 5.84 & 309.88 & 26.72 \\
\hline & & $\mathrm{H} 2 \mathrm{O}$ & 3.20 & 4.32 & 262.84 & 11.86 \\
\hline \multirow[t]{5}{*}{ F. berteroana } & \multirow[t]{2}{*}{ leaves } & EtOAc & 8.49 & 1.67 & 128.23 & 19.14 \\
\hline & & EHO & 19.89 & 3.92 & 312.76 & 19.12 \\
\hline & \multirow[t]{3}{*}{ fruits } & EtOAc & 18.75 & 4.17 & 130.01 & 18.40 \\
\hline & & EHO & 22.25 & 4.94 & 332.67 & 11.24 \\
\hline & & $\mathrm{H} 2 \mathrm{O}$ & 14.93 & 3.32 & 219.87 & 21.77 \\
\hline \multirow[t]{2}{*}{ G. taitensis } & \multirow[t]{2}{*}{ flowers } & EtOAc & 2.49 & 3.11 & 173.78 & 23.93 \\
\hline & & $\mathrm{H} 2 \mathrm{O}$ & 4.79 & 5.99 & 193.01 & 24.74 \\
\hline \multirow[t]{2}{*}{ M. citrifolia } & \multirow[t]{2}{*}{ leaves } & EtOAc & 6.10 & 5.17 & 295.09 & 116.2 \\
\hline & & EHO & 14.66 & 12.43 & 440.06 & 23.48 \\
\hline \multirow{4}{*}{$\begin{array}{l}\text { T. purpurea var. } \\
\text { purpurea }\end{array}$} & bark & EtOAc & 4.82 & 5.95 & 1044.4 & 58.40 \\
\hline & roots & EtOAc & 3.03 & 2.90 & 553.55 & 158.38 \\
\hline & \multirow[t]{2}{*}{ leaves } & EtOAc & 5.04 & 1.68 & 675.20 & 22.09 \\
\hline & & $\mathrm{H} 2 \mathrm{O}$ & 11.24 & 3.75 & 383.20 & 15.05 \\
\hline \multicolumn{5}{|c|}{ Green tea extract (900017 internal reference) } & 15348.23 & 521.02 \\
\hline
\end{tabular}

${ }^{1} \mathrm{EHO}=$ ethanol: water $(1: 1)$ extract

In the 5-LOX assay (Table 5), several compounds fared well compared to our standard Primula veris L., extract (IC $50=0,018 \%$ dry mass). The IC 50 values of the extracts' range between $0.015 \%$ of dry mass and $0.206 \%$ dry mass. The most potent anti-inflammatory extracts are the aqueous ethanolic extract of the bark of $A$. moluccanus (IC $50=0,015 \%$ ), the aqueous extract of $C$. inophyllum leaves (IC $50=0.016 \%$ ) as well as the ethanolic extract of its fruits $(0,021 \%)$. The ethyl acetate extracts of $B$. pilosa and A. moluccanus bark, $T$. purpurea var. purpurea's bark and the fruits of $F$. berteroana also show interesting anti-inflammatory activities.

Table 5 : The anti-inflammatory activities of the plant extracts

\begin{tabular}{|l|l|l|c|}
\hline Plant species & Plant part & $\begin{array}{l}\text { Extraction } \\
\text { solvent }\end{array}$ & $\begin{array}{c}\text { 5-LOX } \\
\text { IC 50 \% dry mass }\end{array}$ \\
\hline A. pavonina & seeds & EtOAc & 0.205 \\
\hline A. moluccanus & leaves & EHO & 0.055 \\
\cline { 2 - 4 } & bark & EtOAc & 0.029 \\
\cline { 3 - 5 } & & EHO & 0.015 \\
\hline B. monnieri & whole plant & EtOAc & 0.065 \\
\hline
\end{tabular}




\begin{tabular}{|c|c|c|c|}
\hline & & $\mathrm{EHO}$ & 0.102 \\
\hline & & $\mathrm{H}_{2} \mathrm{O}$ & 0.073 \\
\hline \multirow[t]{2}{*}{ B. pilosa } & \multirow[t]{2}{*}{ whole plant } & EtOAc & 0.024 \\
\hline & & $\mathrm{EHO}$ & 0.055 \\
\hline \multirow[t]{2}{*}{ C. inophyllum } & leaves & $\mathrm{H}_{2} \mathrm{O}$ & 0.016 \\
\hline & fruits & $\mathrm{EtOH}$ & 0.020 \\
\hline C. fruticosa & leaves & $\mathrm{EHO}$ & 0.134 \\
\hline \multirow[t]{2}{*}{ F. berteroana } & \multirow[t]{2}{*}{ fruits } & EtOAc & 0.041 \\
\hline & & $\mathrm{EHO}$ & 0.040 \\
\hline M. citrifolia & leaves & $\mathrm{EHO}$ & 0.072 \\
\hline T. purpurea var. purpurea & bark & EtOAc & 0.031 \\
\hline \multicolumn{3}{|c|}{ Primula veris referenced extract } & 0.018 \\
\hline
\end{tabular}

${ }^{1} \mathrm{EHO}=$ ethanol: water $(1: 1)$ extract

From the preliminary obtained results (Tables $4 \& 5$ ), a few extracts stood out, such as the aqueous extract of $C$. inophyllum leaves that possess both antioxidant as well as anti-inflammatory activities. The ethyl acetate extract was only tested on the FRAP assay and already demonstrated antioxidant potential similar to that of the aqueous extract. The leaves are not the only interesting plant part as the fruits also showed a potent anti-inflammatory activity. A. moluccanus activities mainly concern the bark and its ethyl acetate extract that mediates both good anti-inflammatory and antioxidant activities, although the EHO extract has better anti-inflammatory potential. The leaves present a mild anti-inflammatory activity. B. pilosa gave more interesting antioxidant and antiinflammatory results more so than the EHO extract. Every F. berteroana whether leaves or fruits revealed very low antioxidant potential, but the fruits extract recorded mild to good antiinflammatory activities. T. purpurea, ethyl acetate bark extract not only proved to be a source of antioxidants but also an anti-inflammatory extract. The results of performed assays confirmed the antioxidant and anti-inflammatory potential of $C$. inophyllum, $A$. moluccanus, B. pilosa, F. berteroana as well as T. purpurea. A limited number of assays were performed on the extracts but nevertheless gave preliminary insight on those most active for further study. This preliminary screening was a step towards determining which extracts would be further studied. Thus, the overall cosmetic potential of the four plants, as well as S. orientialis are hereby discussed according to results from table 3.

\subsubsection{Asteraceae}

\section{Bidens pilosa}

The flowers and leaves showed interesting DPPH activity compared to stems and roots (Cortés-Rojas et al., 2013). The butanol fraction of the plant also shows good antioxidant activity in DPPH, antiradical and to inhibit NO (Chiang et al., 2004). The aqueous extract of the aerial part 
inhibited cyclooxygenase and consequently PGE2 (Yoshida et al., 2006). A plant extract antioxidant activity was shown by inhibition of the production of ROS and activation of NO in endothelial cells of the derma (Kohda et al., 2013). A formulation of B. pilosa/ Curcuma longa L. (125 mg/kg and 15 $\mathrm{mg} / \mathrm{kg}$ ) (Bastos et al., 2015) displayed anti-mucositis activities. The petroleum ether extract of the aerial parts exhibits antimicrobial activity (Geissberger \& Séquin, 1991). The butanol fraction of the whole plant is immunomodulatory (Chang et al., 2007). A combination of antioxidant, antiinflammatory and anti-microbial activities explains its ethnobotanical use to heal knife cut wounds. Furthermore, the ethanol extract of aerial parts inhibits renin and the enzyme converting angiotensin (Chen et al., 2016) which could have a role in alleviating bleeding caused by wounding. This underlines $B$. pilosa potential for development as an effective anti-aging product. This activity was already found in the supercritical $\mathrm{CO}_{2}$ extract of the aerial parts and more specifically phytol (Dieamant et al., 2015). B. pilosa extract has already been patented as a whitening agent (US PATENT: US 2015/0359734 A1). According to this patent, B. pilosa acts as a degrading agent of melanin and affects melanin transport. This mode of action is attributed to its high antioxidant activity and retinoid-like activity (Diemant et al., 2015; Roberts et al., 2015). Its whitening activity seems to be a result of compounds such as caffeic and ferulic acids (Chen et al., 2016) and derivatives, as they are a potent source of anti-tyrosinase compounds (Okombi, 2005).

\section{Sigesbeckia orientalis}

The aerial parts exert an anticancer effect (Chang et al., 2014). They also possess an antiinflammatory activity topically in vivo on carrageenan-induced inflammation in rats (Wang et al., 2011) and through the inhibition of NO production, TNF- $\alpha$, IL- 6 production, reduction of iNOS, suppression of I??B-?? and NF??B phosphorylation in a dose-dependent manner. Also, the $S$. orientalis extract reduced the expression of JNK, p38 and ERK 1 and ERK 2 (Hong et al., 2014). All of these factors are included in the process of skin-ageing. This comforts its traditional use in woundhealing. It is further confirmed by the antimicrobial activity also of kirenol from the hairy roots against Gram-positive bacteria such as Bacillus subtilis, Streptococcus oralis and Staphylococcus aureus (Wang et al., 2012). The anti-inflammatory and antimicrobial activity of S. orientalis aerial parts in line with its traditional use to cure sores, heal wounds and hydrate skin highlights its potential to be developed as an anti-ageing product as well as an anti-blemish agent. The whole plant was found to inhibit the production of Immunoglobulin E (IgE) and thus exert an anti-allergy combined to an anti-inflammatory activity (Hwang et al., 2001), while the ethanol extract of the aerial parts was found to be immunosuppressive (Sun et al., 2006). High levels of IgE influence sensitive skin making it prone to inflammation and leading along with eosinophils (Liu et al., 2011) to atopic dermatitis (Yatagai et al., 2018, Ham et al., 2019). 
S. orientalis also has depigmenting traditional uses (Handy, 1923). The efficiency of $S$. orientalis as a whitening agent would be interesting to investigate thoroughly. Furthermore, testing its retinoid-like activity could potentially show a similar pattern or mode of action as B. pilosa. Indeed, S. orientalis and B. pilosa both belong to the Asteraceae family. The whitening activity of $B$. pilosa could give some insight into $S$. orientalis potential, although these two plants species have a distinct chemical composition. Constituents responsible for the whitening potential of S. orientalis could be flavonoids (Loizzo et al., 2012).

Thus S. orientalis presents potential development as a whitening, anti-blemish and an anti-ageing ingredient.

\subsubsection{Calophyllaceae}

\section{Calophyllum inophyllum}

The acetonides and neoflavonoids synthesized from the nut oil showed anti-bacterial activity against E. coli, Salmonella typhi and Pseudomonas aeruginosa while the oil extract was active against B. subtilis and S. aureus. (Adewuyi et al., 2014). A further antibacterial activity against Proponium acnes was also observed (Léguillier et al., 2015) thus corresponding to an anti-acne or anti-blemish potential. Léguillier et al. (2015) as well as Ansel et al. (2016b) also demonstrated a wound-healing activity of the nut oil further observed along with an anti-inflammatory activity of calophyllolides of the seeds by decreasing IL-1 $1 \beta$, IL-6, TNF- $\alpha$ expression levels in serum of mice (Nguyen et al., 2017). Inophinnin from the dichloromethane extract of the stem bark showed a mild anti-inflammatory activity in the nitric oxide assay on raw cells (Ee et al., 2011). The barks stem is anti-arthritic (Perumal et al., 2017). While the wound-healing properties of tamanu nut oil has been studied, the leaves have garnered less interest, yet they have been used in other parts of Polynesia for similar ailments as the oil. Also, the nut oil is already used by some to promote hair growth, but its mode of action has yet to be fully assessed.

\subsubsection{Euphorbiaceae}

\section{Aleurites moluccanus}

Flavonoids such as swertisin and 2"-O-rhamnosylswertisin are the molecules deemed responsible for the cutaneous anti-inflammatory activity of A. moluccanus (Cesca et al., 2012; Hoepers et al., 2015). The latter, 2"-O-rhamnosylswertisin, also possesses an antinociceptive activity (Cesca et al., 2012; Quintao et al., 2011 \& 2012). $\beta$-sitosterol, stigmasterol, campesterol, $\alpha$ - et $\beta$ - amyrin as well as $\mathrm{n}$-hentriacontane are analgesic (Meyre-Silva et al., 1998). The seed oil is antioxidant and has hydrating properties (Athar \& Nasir, 2005; Ako et al., 2005). The methanol extract of the leaves 
completely inhibited the porcine pancreatic lipase (Ado et al., 2013). The methanol and aqueous extracts of the nut inhibit Proteus mirabilis, exhibiting a potential anti-rheumatic arthritis activity (Cock et al., 2015). Furthermore, polyphenols are compounds that have been very effective to inhibit elastase and collagenase (Zillich et al., 2015). Along with "tamanu" (C. inophyllum), A. moluccanus nut oil or kukui nut oil are already commercialized as massage and anti-aging oils. Nevertheless, its mode of action has not yet been clearly studied and identified to our knowledge. The bark could also be interesting for its anti-aging potential according to its traditional use, although in this case, collecting such a plant part could be very destructive for the tree and serve as a limiting factor to its sustainable use.

\subsubsection{Fabaceae}

\section{Tephrosia purpurea var. purpurea}

The biological activities discussed here correspond to $T$. purpurea and to its synonym $T$. piscatoria. Along with other plants from this genus, $T$. purpurea has a high rotenoid content that is responsible for its ichtyotoxic activity. Lanceolatins, found as constituents of $T$. purpurea stems, were also formerly extracted from Cephalotaxus lanceolate and were shown having both an antiinflammatory activity by inhibiting NO in macrophages and an anti-tumoral activity through cytotoxicity against several tumoral cell lines (He et al., 2015). An ethanolic extract of T. purpurea aerial parts showed wound-healing properties by enabling proper collagen and fibroblast formation, as well as epithelization, increasing tensile strength after incision and in the dead space wound model on rats (Lodhi et al., 2006). According to our literature review of traditional uses and biological activities, T. purpurea is most suited for a potential anti-aging development.

\subsubsection{Gentianaceae}

\section{Fagraea berteroana}

The chemical composition of $F$. berteroana is not extensively studied apart from its flowers and their volatile compounds (Hayashi et al., 1995). Thus, very little is known of the chemical composition of the fruits. Several other plants of the genus Fagraea have been studied and a diverse range of compounds have been isolated from several parts and compiled (Guezennec et al., 2005). According to other plants of the Fagraea genus, the fruits could contain monoterpenes alkaloids. Hence, the lack of knowledge of the chemical composition of $F$. berteroana and little research that has been conducted on the plant, proposes it as an original candidate for further study in hair care. This activity might be supported by compounds such as 3,4-dimethoxycinnamic acid, as sinapic acid (3,5dimethoxy-4-hydroxycinnamic acid) has shown a hair growth activity by activating the Wnt pathway 
through phosphorylating GSK3 $\beta$ and stimulating the production of $\beta$-catenin as well as boosting cell cycle progression of HFDPC by upregulating factors IGF and VEGF (Woo et al., 2017).

\section{Conclusion}

Eleven plants were selected, both native (indigenous) and introduced ones (Polynesian and modern) of the French Polynesian flora, that show promise to be further studied and developed as cosmetic ingredients. Although we did not investigate the endemic potential of the flora of French Polynesia, we were still able to find active extracts and knowledge to increase our limited grasp of ethnocosmetopoeia in this region. The chosen plants have traditional Polynesian uses that are relevant in determining their cosmetic development potential. Literature review and preliminary biochemical screenings were the first steps to determine which plants and plant parts were most active and what cosmetic applications were most relevant when refered to the identified traditional uses. Several extracts stood out for future bioassays and deeper studies. The ethyl acetate and aqueous ethanol extracts of $F$. berteroana fruits, the ethyl acetate extracts of $B$. pilosa and $T$. purpurea, $C$. inophyllum extracts and $S$. orientalis deserve more investigation for their anti-ageing potential, hair growth promotion and skin whitening. The bark extracts of $A$. moluccanus should not be considered as they are not renewable plant parts. Further studies will be necessary to propose pertinent natural and effective cosmetic ingredients with minimal, to no side effects. Finding active compounds from the Polynesian cosmetopoeia would be a rewarding form of cosmetic ingredient sourcing because hair and skin maintenace is an important aspect of Polynesian culture.

Focusing on folk cosmetics is an attractive aspect of plant sourcing as only $15 \%-20 \%$ of plants around the world have been phytochemically assessed. Yet, many countries abound with plant resources and combined traditional cosmetic knowledge with no prior scientific assessment or study. Preservation of this traditional knowledge of cosmetopoeia and new findings of modern pertinent cosmetic applications of the related plants could be a promising sector of sustainable development and bring new income for these countries.

\section{Declaration of interest}

The authors declare that there are no conflicts of interest.

\section{Acknowledgements}

We thank the French Ministry of Higher Education and Research and Greentech that provided the PhD grant. We are also grateful to the plant suppliers in the Marquesas Islands, Christian Taata, Joan Augereau and Jérôme Simonneau, and Tamatoa Lehartel in Taravao, Tahiti. 


\section{References}

Adebiyi, O.E., Olayemi, F.O., Ning-Hua, T., Guang-Zhi, Z., 2017. In vitro antioxidant activity, total phenolic and flavonoid contents of ethanol extract of stem and leaf of Grewia carpinifolia. Beni-Suef University Journal of Basic and Applied Sciences 6, 10-14.

Adewuyi, A., Fasusi, O.H., Oderinde, R.A., 2014. Antibacterial activities of acetonides prepared from the seed oils of Calophyllum inophyllum and Pterocarpus osun. Journal of Acute Medicine 4, 75-80.

Ado M. A., Abas F., Mohammed A. S., Ghazali H. M., 2013. Anti- and pro-lipase activity of selected medicinal, herbal and aquatic plants, and structure elucidation of an anti-lipase compound. Molecules. 18, 1465114669.

Agyare, C., Boakye, Y.D., Bekoe, E.O., Hensel, A., Dapaah, S.O., Appiah, T., 2016. Review: African medicinal plants with wound healing properties. Journal of Ethnopharmacology. 177, 85-100.

Ahmad V. U., Ali Z., Hussaini S.R., Iqbal F., Zahid M., Abbas M., Saba N., 1999. Flavonoids of Tephrosia purpurea. Fitoterapia. 70, 443-445.

Ahshawat, M.S., Saraf, S., Saraf, S., 2008. Preparation and characterization of herbal creams for improvement of skin viscoelastic properties. International Journal of Cosmetic Science 30, 183-193.

Aitken RT., 1930. Ethnology of Tubuai. Bernice P. Bishop Museum 70. Honolulu, Hawaii: Bishop Museum.

Akihisa T., Matsumoto K., Tokuda H., Yasukawa K., Seino K., Nakamoto K., Kuninaga H., Suzuki T., Kimura Y., 2007. Anti-inflammatory and potential cancer chemopreventive constituents of the fruits of Morinda citrifolia (Noni). Journal of Natural Products. 70, 754-757.

Ako H., Kong N., Brown A., 2005. Fatty acid profiles of kukui nut oils over time and from different sources. Industrial crops and products. 22, 169-174.

Akula, U.S., Odhav, B., 2008. In vitro 5-Lipoxygenase inhibition of polyphenolic antioxidants from undomesticated plants of South Africa. Journal of Medicinal Plants Research. 2, 207-212.

Ali M. S., Ahmed F., Azhar I., Pervez M. K., 2005. Pavonin: A new five-membered lactone from Adenanthera pavonina Linn. (Mimoaceae), Natural Product Research. 19, 37-40.

Ansel J-L., Butaud J-F., Raharivelomanana P., 2016a. Bibliographical analysis of main lignified taxons used in tropical cosmetopoiea. Comptes Rendus Chimie. 19, 1035-1048.

Ansel, J.-L., Lupo, E., Mijouin, L., Guillot, S., Butaud, J.-F., Ho, R., Lecellier, G., Raharivelomanana, P., Pichon, C., 2016b. Biological Activity of Polynesian Calophyllum inophyllum Oil Extract on Human Skin Cells. Planta Medica 82, 961-966.

Ansel J-L., Ly Q., Butaud J-F., Nicolas M., Herbette G., Peno-Mazzarino L., Lati E., Raharivelomanana P., $2016 \mathrm{c}$. Anti-ageing activity of Fitchia nutans, a cosmeticeutical ingredient of a Polynesian traditional monoï. Comptes Rendus Chimie. 19, 1049-1055.

Ara A., Arifuzzaman M., Ghosh C. K., Md. Hashem A., Ahmad M. U., Bachar S. C., Nahar L., Sarker S. D., 2010. Anti-inflammatory activity of Adenanthera pavonina L., Fabaceae, in experimental animals. Brazilian Journal of Pharmacognosy. 20, 929-932. 
Athar M., Nasir S. M., 2005. Taxonomic perspective of plant species yielding vegetable oils used in cosmetics and skin care products. African Journal of Biotechnology. 4, 36-44.

Banerjee, P.S., Sharma, M., Nema, R.K., 2009. Preparation, evaluation and hair growth stimulating activity of herbal hair oil. Journal of Chemical and Pharmaceutical Research. 1, 261-267.

Baruah R. N., Sharma R. P., Madhusudanan K. P., Hygarajan G., Herz W., Murari R., 1979. A new melampolide from Sigesbeckia orientalis. Phytochemistry. 18, 991-994.

Basir, D., Hanafi, M., Julinar, Saputra, A., Wati, T., 2018. Free Solvent Amidation of Ursolic and Oleanolic Acids of Fagraea Fragrans Fruits: Their P-388 Antitumor Activity. Journal of Physics: Conference Series 1095, 012006.

Bass, D.A., 1975. Behavior of eosinophil leukocytes in acute inflammation. II. Eosinophil dynamics during acute inflammation. Journal of Clinical Investigation 56, 870-879.

Benzie, I.F.F., Strain, J.J., 1996. The Ferric Reducing Ability of Plasma (FRAP) as a Measure of "Antioxidant Power" : The FRAP Assay. Analytical Biochemistry. 239, 70-76.

Cunha Bastos C. C., de Avila P. H. M., dos Santos Filho E. X., de Avila R. I., Carvalho Batista A., Gonçalves Fonseca S., Martins Lima E., Neves Marreto R., de Mendonça E. F., Valadares M. C., 2015. Use of Bidens pilosa L. (Asteraceae) and Curcuma longa L. (Zingiberaceae) to treat intestinal mucositis in mice: toxicopharmacological evaluations. Toxicology Reports. 3, 279 -287.

Berlotto C., Busca R., Ballotti R., Ortonne J-P., 2001. L'AMP cyclique est un régulateur de la pigmentation de la peau. Médecine/sciences. 17, 177-185.

Bhadada S. V., Vyas V. K., Goyal R. K., 2016. Protective effect of Tephrosia purpurea in diabetic cataract through aldose reductase inhibitory activity. Biomedicine \& Pharmacotherapy. 83, 221-228.

Bhandari P., Kumar N., Singh B., Kaul V. K., 2007. Bacosterol glycoside, a new 13,14-seco-steroid glycoside from Bacopa monnieri. Chem. Pharm. Bull. 54, 240-241.

Billo, M., Cabalion, P., Waikedre, J., Fourneau, C., Bouttier, S., Hocquemiller, R., Fournet, A., 2005. Screening of some New Caledonian and Vanuatu medicinal plants for antimycobacterial activity. Journal of Ethnopharmacology 96, 195-200.

Boland P., Schwarz J., Bouche D. E., 2015. Formulations for lightening skin and treating hyperpigmentation. US PATENT: US 2015/0359734 A1. Carlsbad, California.

Boggs L. A., Smith F., 1956. The constitution of the glucofructan of the tuber of the Hawaiian "Tl" plant (Cordyline terminalis). Journal of the American Chemical Society. 78, $1880-1885$.

Brown, F.B.H. 1935. Flora of southeastern Polynesia. III. Dicotyledons. Bernice P. Bishop Museum Bulletin 130. Honololu, Hawaii: Bishop Museum.

Butaud J-F., 2013. Synthèse bibliographique portant sur les plantes utilisées dans la cosmétopée de Polynésie française, Papeete.

Cambie R.C., Lal A.R., Rickard C.E.F., Tanaka N., 1990. Chemistry of Fijian plants. V. Constituents of Fagracea gracilipes A. Gray. Chemical and Pharmaceutical Bulletin. 38, 1857-1861.

Carlson, M.E., Silva, H.S., Conboy, I.M., 2008. Aging of signal transduction pathways, and pathology. Experimental Cell Research 314, 1951-1961. 
Cesca T.G, Faqueti L. G., Rocha L.W, Meira N. A., Meyre-Silva C., de Souza M.M., Quintão N.L.M., Silva R.M.L., Cechinel Filho V., Bresolin T.M.B., 2012. Antinociceptive, anti-inflammatory and wound healing features in animal models treated with a semisolid herbal medicine based on Aleurites moluccana L. Willd. Euforbiaceae standardized leaf extract Semisolid Herbal. Journal of Ethnopharmacology. 143, 355-362.

Chandra S., Verma M. Saxena H., 1982. Triterpenoids of Adenanthera pavonina root. International Journal of Crude Drug Research. 20, 165-167.

Chang S-L., Chiang Y-M., Chang C. L-T., Yeh H-H., Shyur L-F., Kuo Y-H., Wu T-K., Yang W-C., 2007. Flavonoids, centaurein and centaureidin, from Bidens pilosa, stimulate IFN- $\gamma$ expression. Journal of Ethnopharmacology. 112, 232-236.

Chang C-C., Hsu H-F., Huang K-H., Wu J-M., Kuo S-M., Ling X-H., Houng J-Y., 2014. Anti-proliferative effects of Siegesbeckia orientalis ethanol extract on human endometrial RL-95 cancer cells. Molecules. 19, 1998019994.

Chen Y., Luo J., Zhang Q., Kong L., 2016. Identification of active substances for dually modulating the reninangiotensin system in Bidens pilosa by liquid chromatography-mass spectrometry-based chemometrics. Journal of Functional Foods. 21, 201-211.

Chiang Y-M., Chuang D-Y., Wang S-Y., Kuo Y-H., Tsai P-W., Shyur L-F., 2004. Metabolite profiling and chemopreventive bioactivity of plant extracts from Bidens pilosa. Journal of Ethnopharmacology. 95, 409419.

China Food and Drug Administration (CFDA), 2015. Inventory of Existing Cosmetic Ingredients in China (CFDA, Decree No.105, 2015).

Chopra, R.N., Nayar, S.L., Chopra, I.C., 1956. Glossary of Indian medicinal plants. Council of Scientific and Industrial Research: New Delhi, India. 347 p.

Christian F. W., 1897. On the distribution and origin of some plant- and tree-names in Polynesia and Micronesia. Journal of the Polynesian Society. 6, 123-140.

Claude-Lafontaine A., Raharivelomanana P., Bianchini J-P., Schippa C., Azzaro M., Cambon A., 1992. Volatile constituents of the flower concrete of Gardenia taitensis DC. Journal of Essential Oil Research. 4, 335-343.

Cock I. E., Winnett V., Sirdaarta J., Matthews B., 2015. The potential of selected Australian medicinal plants with anti-Proteus activity for the treatment and prevention of rheumatoid arthritis. Pharmacognosy Magazine. 11, 190-208.

Cortés-Rojas D. F., Chagas-Paula D. A., Da Costa F. B., Souza C. R. F., Oliveira W. P., 2013. Bioactive compounds in Bidens pilosa L. populations: a key step in the standardization of phytopharmaceutical preparations. Brazilian Journal of Pharmacognosy. 23, 28-35.

Costin G-E., Vincent J. Hearing V. J., 2007. Human skin pigmentation: melanocytes modulate skin color in response to stress. THE FASEB Journal. 21, 976 -994.

Cuendet M., Hostettmann K., Potterat O., Dyatmiko W., 1997. Iridoid glucosides with free radical scavenging properties from Fagraea blumei. Helvetica Chimica Acta. 80, 1144-1152. 
Cui, R., Widlund, H.R., Feige, E., Lin, J.Y., Wilensky, D.L., Igras, V.E., D’Orazio, J., Fung, C.Y., Schanbacher, C.F., Granter, S.R., Fisher, D.E., 2007. Central Role of p53 in the Suntan Response and Pathologic Hyperpigmentation. Cell 128, 853-864.

Cui, B., Zhang, S., Wang, Y., Guo, Y., 2019. Farrerol attenuates $\beta$-amyloid-induced oxidative stress and inflammation through Nrf2/Keap1 pathway in a microglia cell line. Biomedicine \& Pharmacotherapy 109, 112-119.

da Silva D. B., Fernandes E. F. A., de Santis Ferreira L., Callejon D. R., Guaratini T., Callegari Lopes J. N., MeyreSilva C., Cechinel Filho V., Lopes N. P., 2012. Megastigmanes from Aleurites moluccana (L.) Willd. (Euphorbiaceae). Biochemical Systematics and Ecology. 40, 34-37.

de Godoi A. M., Faccin-Galhardi L. C., Lopes N., Zendrini Rechenchoski D., de Almeida R. R., Pontes Silva Ricardo N. M., Nozawa C., Carvalho Linhares R. E., 2014. Antiviral activity of sulfated polysaccharide of Adenanthera pavonina against poliovirus in HEp-2 Cells. Evidence-Based Complementary and Alternative Medicine. DOI: 10.1155/2014/712634.

Davies N. W., Miller J. M., Naidu R., Sotheeswaran S., 1992. Triterpenoids in bud exudates of Fijian Gardenia species. Phytochemistry. 31, 159- 162.

Dieamant G., Pereda M. C. V., Nogueira C., Eberlin S., Facchini G., Tibério Checon J., Kappke Cesar C., Mussi L., Polezel M. A., Martins-Oliveira Jr. D., Di Stasi L. C., 2015. Antiageing mechanisms of a standardized supercritical CO2 preparation of Black Jack (Bidens pilosa L.) in human fibroblasts and skin fragments. Evidence-Based Complementary and Alternative Medicine. DOI: 0.1155/2015/280529.

Dweck, A.C., Meadows, T., 2002. Tamanu (Calophyllum inophyllum) - the African, Asian, Polynesian and Pacific Panacea. International Journal of Cosmetic Science 24, 341-348.

Ee, G.C.L., Mah, S.H., Rahmani, M., Taufiq-Yap, Y.H., Teh, S.S., Lim, Y.M., 2011. A new furanoxanthone from the stem bark of Calophyllum inophyllum. Journal of Asian Natural Products Research 13, 956-960.

Ezeagu I. E., Gopal Krishna A. G., Khatoon S., Gowda L. R., 2004. Physico-chemical characterization of seed oil and nutrient assessment of Adenanthera pavonina, L: an underutilized tropical legume. Ecology of Food and Nutrition. 43, 295-305.

Farine J-P., Legal L., Moreteau B., Quere J-L., 1996. Volatile components of ripe fruits of Morinda citrifolia and their effects on Drosophila. Phytochemistry, 41, 433-438.

Florence J., Chevillotte H., Ollier C., Meyer J.-Y, 2007. Base de données botaniques Nadeaud de I'Herbier de la Polynésie française (PAP). http://www.herbier-tahiti.pf

Florence, J., Moretti, C., 2006. Les ressources végétales polynésiennes, In: Guezennec, J., Moretti, C., Simon, J.C. (Eds.), Substances naturelles en Polynésie française. IRD Éditions, pp. 3-36.

Fouedjou R. T., Teponno R. B., Quassinti L., Bramucci M., Petrelli D., Vitali L. A., Fiorini D., Tapondjou L. A., Barboni L., 2014. Steroidal saponins from the leaves of Cordyline fruticosa (L.) A. Chev. and their cytotoxic and antimicrobial activity. Phytochemistry Letters. 7, 62-68.

Fourdrigniez, M., Meyer J.-Y., 2008. Liste et caractéristiques des plantes introduites naturalisées et envahissantes en Polynésie française. Contribution à la Biodiversité de Polynésie française $\mathrm{N}^{\circ} 17$. Délégation à la Recherche, Papeete, 62 pages + Annexe 
Garai S., Mahato S. B., Ohtani K., Yamasaki K., 1996. Dammarane-type triterpenoid saponins from Bacopa monniera. Phytochemistry. 42, 815-820.

Geissberger P., Sequin U., 1991. Constituents of Bidens pilosa L.: Do the components found so far explain the use of this plant in traditional medicine? Acta Tropica. 48, 251-261.

Gennaro A., Merlini L., Nasini G., 1972. Leguminosae flavonoids from Adenanthera pavonina. Phytochemistry. 11, 1515.

Gilhar, A., Keren, A., Paus, R., 2019. JAK inhibitors and alopecia areata. The Lancet 393, 318-319.

Girardi C., Butaud J.F., Ollier C., Ingert N., Weniger B., Raharivelomanana P., Moretti C., 2015. Herbal medicine in the Marquesas islands. Journal of Ethnopharmacology. 161, 200-213.

Grépin F. \& Grépin M., 1984. La medicine tahitienne traditionnelle. Raau Tahiti. Paris, France: Les Editions du Pacifique.

Grombone-Guaratinia M. T., Silva-Brandaõ K. L., Solferinia V. N., Semir J., Trigo J. R., 2005. Sesquiterpene and polyacetylene profile of the Bidens pilosa complex (Asteraceae: Heliantheae) from Southeast of Brazil. Biochemical Systematics and Ecology. 33, 479-486.

Guezennec J., Moretti C., Simon J.-C., 2005. Substances naturelles en Polynésie française. Stratégies de valorisation, Paris, IRD Éditions, 304 p.

Ham, B., Kim, M., Son, Y.-J., Chang, S., Jung, S.H., Nho, C.W., Kwon, M.J., 2019. Inhibitory Effects of Pterocarpus santalinus Extract against IgE/Antigen-Sensitized Mast Cells and Atopic Dermatitis-Like Skin Lesions. Planta Medica.

Han, G., 2017. The Changing Landscape of Alopecia Areata: An Introduction. Advances in Therapy 34, 15841585.

Handy E. S. C., 1923. The native culture in the Marquesas. Bernice P. Bishop Museum: Honolulu, Hawaii.

Hayashi S., Kameoka H., Hashimoto S., Furukawa K., Arai T., 1995. Volatile compounds of Fagraea berteriana flowers. Journal of Essential Oil Research. 7, 505-510.

He, Y.-R., Shen, Y.-H., Shan, L., Yang, X., Wen, B., Ye, J., Yuan, X., Li, H.-L., Xu, X.-K., Zhang, W.-D., 2015. Diterpenoid lanceolatins A-G from Cephalotaxus lanceolata and their anti-inflammatory and anti-tumor activities. RSC Advances 5, 4126-4134.

Hegazy M-E. F., Abd El-Razek M. H., Nagashima F., Asakawa Y., Paré P. W., 2009. Rare prenylated flavonoids from Tephrosia purpurea. Phytochemistry. 70, 1474-1477.

Hibino, T., Nishiyama, T., 2004. Role of TGF- $\beta 2$ in the human hair cycle. Journal of Dermatological Science 35, 9-18.

Higgins, C.A., Petukhova, L., Harel, S., Ho, Y.Y., Drill, E., Shapiro, L., Wajid, M., Christiano, A.M., 2014. FGF5 is a crucial regulator of hair length in humans. Proceedings of the National Academy of Sciences 111, 1064810653.

Hirasumi A., Furusawa E., 1999. An immunomodulatory polysaccharide-rich substance from the fruit juice of Morinda citrifolia (Noni) with antitumour activity. Phytotherapy Research. 13, 380-387.

Hoepers S. M., Tolentino de Souza H. G. M., Quintão N. L.M., Santin J. R., Filho V. C., daSilva R. M. L., Garcia Couto A., Bortolini Simão da Silva K. A. et al., 2015. Topical anti-inflammatory activity of semisolid 
containing standardized Aleurites moluccana L. Willd (Euphorbiaceae) leaves extract. Journal of Ethnopharmacology. 173, 251-255.

Holdsworth D., Rali T., 1989. A Survey of medicinal plants of the Southern Highlands, Papua New Guinea. International Journal of Crude Drug Research. 27, 1-8.

Hong Y-H., Weng L-W., Chang C-C., Hsu H-F., Wang C-P., Wang S-W., Houng J-Y., 2014. Anti-inflammatory effects of Siegesbeckia orientalis ethanol extract in in vitro and in vivo models. BioMed Research International. DOI: 10.1155/2014/329712.

Hwang W-J., Park E-J., Jang C-H., Han S-W., Oh G-J., Kim N-S., Kim H-M., 2001. Inhibitory effect of immunoglobulin E production by Jin-deuk-chal (Siegesbeckia orientalis). Immunopharmacology And Immunotoxicology. 23, 555-563.

Inoue K., Nayeshiro H., Inouye H., Zenk M., 1981. Anthraquinones in cell suspension cultures of Morinda citrifolia. Phytochemistry. 20, 1693-1700.

Inui, S., Itami, S., 2011. Molecular basis of androgenetic alopecia: From androgen to paracrine mediators through dermal papilla. Journal of Dermatological Science 61, 1-6.

Itoigawa, M., Ito, C., Tan, H.T.-W., Kuchide, M., Tokuda, H., Nishino, H., Furukawa, H., 2001. Cancer chemopreventive agents, 4-phenylcoumarins from Calophyllum inophyllum. Cancer Letters 169, 15-19.

Jarić, S., Kostić, O., Mataruga, Z., Pavlović, D., Pavlović, M., Mitrović, M., Pavlović, P., 2018. Traditional woundhealing plants used in the Balkan region (Southeast Europe). Journal of Ethnopharmacology 211, 311328.

Joshi L. S., Pawar, H.A., 2015. Herbal Cosmetics and Cosmeceuticals: An Overview. Natural Products Chemistry Research. 3, 170. doi: 10.4172/2329-6836.1000170.

Jost X., Ansel J.-L., Lecellier G., Raharivelomanana P., Butaud J.-F., 2016. Ethnobotanical survey of cosmetic plants used in Marquesas Islands. Journal of Ethnobotany and Ethnomedecine. 12, DOI: 10.1186/s13002016-0128-5.

Juma W. P., Akala H. M., Eyase F. L., Muiva L. M., Heydenreich M., Okalebo F. A., Gitu P. M., Peter M. G., Walsh D. S., Imbuga M., Yenesew A., 2011. Terpurinflavone: An antiplasmodial flavone from the stem of Tephrosia purpurea. Phytochemistry Letters. 4, 176-178.

Kamiya K., Tanaka Y., Endang H., Umar M., Satake T., 2004. Chemical constituents of Morinda citrifolia fruits inhibit copper-induced low-density lipoprotein oxidation. Journal of Agriculture and Food Chemistry. 52, $5843-5848$.

Kamiya K., Tanaka Y., Endang H., Umar M., Satake T., 2005. New anthraquinone and iridoid from the fruits of Morinda citrifolia. Chem. Pharm. Bull. 53, 1597-1599.

Khalafalah, A. K., Yousef, A. H., Esmail, A. M., Abdelrazik, M. H., Hegazy, M. E., \& Mohamed, A. E., 2010. Chemical constituents of Tephrosia purpurea. Pharmacognosy research. 2, 72-75.

Khan, N.U.-D., Parveen, N., Singh, M.P., Singh, R., Achari, B., Dastidar, P.P.G., Dutta, P.K., 1996. Two isomeric benzodipyranone derivatives from Calophyllum inophyllum. Phytochemistry 42, 1181-1183. https://doi.org/10.1016/0031-9422(96)00049-0 
Kishore, L., Kaur, N., Singh, R., 2017. Bacosine isolated from aerial parts of Bacopa monnieri improves the neuronal dysfunction in Streptozotocin-induced diabetic neuropathy. Journal of Functional Foods. 34, 237-247.

Kohda, F., Takahara, M., Hachiya, A., Takei, K., Tsuji, G., Yamamura, K., Furue, M., 2013. Decrease of reactive oxygen species and reciprocal increase of nitric oxide in human dermal endothelial cells by Bidens pilosa extract: A possible explanation of its beneficial effect on livedo vasculopathy. Journal of Dermatological Science 72, 75-77.

Koodalingam A., Manikandan R., Indhumathi M., Kaviya E. S., 2015. Cytoprotective and anti-inflammatory effects of kernel extract from Adenanthera pavonina on lipopolysaccharide-stimulated rat peritoneal macrophages. Asian Pacific Journal of Tropical Medicine. 8, 112-119.

Krauss B. H., 1974. Ethnobotany of Hawaii. Mānoa, Hawaii: Department of Botany, University of Hawaii.

Kun-Anake A., Ragvatin C., 1976. Bitter glucoside from the leaves of Kangrau. Bulletin of the Department of Medical Sciences. 18, 1-11.

Kwack, M.H., Kim, M.K., Kim, J.C., Sung, Y.K., 2012. Dickkopf 1 Promotes Regression of Hair Follicles. Journal of Investigative Dermatology 132, 1554-1560.

Lei, L., Zeng, Q., Lu, J., Ding, S., Xia, F., Kang, J., Tan, L., Gao, L., Kang, L., Cao, K., Zhou, J., Xiao, R., Chen, J., Huang, J., 2017. MALAT1 participates in ultraviolet B-induced photo-aging via regulation of the ERK/MAPK signaling pathway. Molecular Medicine Reports 15, 3977-3982.

Léguillier T., Lecsö-Bornet M., Lémus C., Rousseau-Ralliard D., Lebouvier N., Hnawia E., Nour M., Aalbersberg W., Ghazi K., Raharivelomanana P. and Rat P., 2015. The wound healing and antibacterial activity of five ethnomedical Calophyllum inophyllum oils: an alternative therapeutic strategy to treat infected wounds, Plos One, DOI: 10.1371/journal.pone.0138602

Li, W., Man, X.-Y., Li, C.-M., Chen, J.-Q., Zhou, J., Cai, S.-Q., Lu, Z.-F., Zheng, M., 2012. VEGF induces proliferation of human hair follicle dermal papilla cells through VEGFR-2-mediated activation of ERK. Experimental Cell Research 318, 1633-1640.

Li, Z., Li, Y., Qin, N., Li, D., Liu, Z., Liu, Q., Hua, H., 2016. Four new coumarins from the leaves of Calophyllum inophyllum. Phytochemistry Letters 16, 203-206.

Lindamulage I. K. S., Soysa P., 2016. Evaluation of anticancer properties of a decoction containing Adenanthera pavonina L. and Thespesia populnea L. BMC Complementary and Alternative Medicine 16, DOI: $10.1186 / \mathrm{s} 12906-016-1053-9$

Liu G., Bode A., Ma W-Y., Sang S., Ho C-T., Dong Z., 2001. Two novel glycosides from the fruits of Morinda citrifolia (noni) inhibit Ap-1 transactivation and cell transformation in the mouse epidermal Jb6 cell line. Cancer Research. 61, 5749-5756.

Liu H., Di Y., Yang J., Teng F., Lu Y., Ni W., Chen C., Hao X., 2008. Three novel 3,4-seco-podocarpane trinorditerpenoids from Aleurites moluccana. Tetrahedron Letters. 49, 5150-5151.

Liu, F.-T., Goodarzi, H., Chen, H.-Y., 2011. IgE, Mast Cells, and Eosinophils in Atopic Dermatitis. Clinical Reviews in Allergy \& Immunology 41, 298-310. 
Lodhi, S., Pawar, R.S., Jain, A.P., Singhai, A.K., 2006. Wound healing potential of Tephrosia purpurea (Linn.) Pers. in rats. Journal of Ethnopharmacology 108, 204-210.

Loizzo, M.R., Tundis, R., Menichini, F., 2012. Natural and synthetic tyrosinase inhibitors as antibrowning agents: an update. comprehensive reviews in food science and food safety $11,378-398$.

Lu, G.-Q., Wu, Z.-B., Chu, X.-Y., Bi, Z.-G., Fan, W.-X., 2016. An investigation of crosstalk between Wnt/ $\beta$-catenin and transforming growth factor- $\beta$ signaling in androgenetic alopecia: Medicine 95, e4297. DOI: 10.1097/MD.0000000000004297

Mah, S.H., Ee, G.C.L., Teh, S.S., Sukari, M.A., 2015. Antiproliferative xanthone derivatives from Calophyllum inophyllum and Calophyllum soulattri. Pakistan Journal of Pharmaceutical Sciences. 28, 425-429.

Martin, A., 2007. The Enlightenment in Paradise: Bougainville, Tahiti, and the Duty of Desire. EighteenthCentury Studies 41, 203-216.

Masuda M., Murata K., Fukuhama A., Naruto S., Fujita T., Uwaya A., Isami F., Matsuda H., 2009. Inhibitory effects of constituents of Morinda citrifolia seeds on elastase and tyrosinase. Journal of Natural Medicine. $63,267-273$.

Mayuren C., Ilavarasan R., 2009. Anti-inflammatory activity of ethanolic leaf extracts from Adenanthera pavonina (L) in rats. Journal of Young Pharmacognosy. 1, 125-128.

McClatchey W., 1996. The ethnopharmacopoeia of Rotuma. Journal of Ethnopharmacology 50, 147-156.

Mckoy M-L. G., Thomas E. A., Simon O. R., 2002. Preliminary investigation of the anti-inflammatory properties of an aqueous extract from Morinda citrifolia (Noni). Proc. West. Pharmacol. Soc. 45, 76-78.

Meyre-Silva C., Mora T. C., Soares Santos A. R., Dal Magro J., Yunes R. A, Delle Monache F., Cechinel-Filho V., 1997. A triterpene and a flavonoid c-glycoside from Aleurites moluccana L. Willd. (Euphorbiaceae). Acta Farm. Bonaerense. 16, 169-172.

Meyre-Silva C., Moral T. C., Biavatti M. W., Santos A. R. S., Dal-Magro J., Yunes R. A., Cechinel-Filho V., 1998. Preliminary phytochemical and pharmacological studies of Aleurites moluccana leaves [L.] Willd. Phytomedicine. 5(2), 109-113.

Miller J. M., Naidu R., Sotheeswaran S., 1989. Unusual flavonols from bud exudates of Fijian Gardenia (Rubiaceae). Indian Journal of Chemistry. 28B, 1093 -1095.

Mohammed R.S., Abou Zeid A.H., El-Kashoury E.A., Sleem A.A., Waly D.A., 2014. A new flavonol glycoside and biological activities of Adenanthera pavonina L. leaves. Natural Product Research. 28, 282-289.

Nakashima M., Shigekuni Y., Obi T., Shiraishi M., Miyamoto A., Yamasaki H., Etoh T., Iwai S., 2011. Nitric oxidedependent hypotensive effects of wax gourd juice. Journal of Ethnopharmacology. 138, 404- 407.

Nayak B. S., Sandiford S., Maxwell A., 2009. Evaluation of the wound-healing activity of ethanolic extract of Morinda citrifolia L. leaf. Evidence-Based Complementary and Alternative Medicine. 6, 351-356.

Nemetchek M. D., Stierle A. A., Stierle D. B., Lurie D. I., 2017. The Ayurvedic plant Bacopa monnieri inhibits inflammatory pathways in the brain. Journal of Ethnopharmacology. 197, 92-100.

Nigam S. K., Misra G., Mitra C. R., 1973. Stigmasterol glucoside a constituent of Adenanthera pavonina seed and leaf. Planta medica. 23, 145-148. 
Nguyen et al., 2017 CAI Nguyen V-L., Truong C-T., Nguyen BCQ., Vo T-NV., Dao T-T., Nguyen V-D., 2017. Antiinflammatory and wound healing activities of calophyllolide isolated from Calophyllum inophyllum Linn. PLoS ONE. 12, e0185674.

Oh, J.W., Kloepper, J., Langan, E.A., Kim, Y., Yeo, J., Kim, M.J., Hsi, T.-C., Rose, C., Yoon, G.S., Lee, S.-J., Seykora, J., Kim, J.C., Sung, Y.K., Kim, M., Paus, R., Plikus, M.V., 2016. A Guide to Studying Human Hair Follicle Cycling In Vivo. Journal of Investigative Dermatology 136, 34-44.

Okombi S., 2005. Recherche et étude de molécules à activité antityrosinase et leur utilisation comme agents dépigmentants en dermocosmétique. Thesis in Organic Chemistry. University Joseph-Fourier - Grenoble I, 2005. French. <tel-00846562>

Okuyama E., Suzumura K., Yamazaki M., 1995. Pharmacologically active components of Todopon Puok (Fagraea racemosa), a medicinal plant from Borneo. Chemical and Pharmaceutical Bulletin. 43, 2200-2204.

Olajide O. A., Echianu C. A., Adedapo A. D. A., Makinde J. M., 2004. Anti-inflammatory studies on Adenanthera pavonina seed extract. Inflammopharmacology. 12, 197-202.

Pandhare R. B., Sangameswaran B., Mohite P. B., Khanage S. G., 2012. Anti-hyperglycaemic and lipid lowering potential of Adenanthera pavonina Linn. in streptozotocin induced diabetic rats. Orient Pharm Exp Med. 12, 197-203.

Perumal S. S., Ekambaram S. P., Dhanam T., 2017. In vivo antiarthritic activity of the ethanol extracts of stem bark and seeds of Calophyllum inophyllum in Freund's complete adjuvant induced arthritis. Pharmaceutical Biology. 55, 1330-1336.

Pervin, S., Ranchhod, A., Wilman, M., 2014. Trends in cosmetics purchase: Ethical perceptions of consumers in different cultures. A cross country comparative study between South Asian and Western consumers. Journal of Customer Behaviour 13, 57-72.

Pétard P., 1986. Plantes utiles de Polynésie et Raau Tahiti. Haere po no Tahiti : Papeete, 354 p.

Plikus, M.V., 2012. New Activators and Inhibitors in the Hair Cycle Clock: Targeting Stem Cells' State of Competence. Journal of Investigative Dermatology 132, 1321-1324.

Prabowo, W.C., Wirasutisna, K.R., Insanu, M., 2013. Isolation and characterization of 3-acetyl aleuritolic acid and scopoletin from stem bark of Aleurites moluccana (L.) Willd. International Journal of Pharmacy and Pharmaceutical Sciences. 5, 851-853.

Qasim M. A., Roy S. K., Kamil M., llyas M., 1987. A new glycosyl flavone from Fagraea obovata wall. Phytochemistry. 26, 2871-2872.

Quintao et al., 2011. Aleurites moluccana (L.) Willd. Leaves: mechanical antinociceptive properties of a standardized dried extract and its chemical markers. Evidence-Based Complementary and Alternative Medicine.

Quintão N. L. M., Antonialli C. S., da Silva G. F., Rocha L. W., de Souza M. M., Malheiros A., Meyre-Silva C., Lucinda-Silva R. M., Bresolin T. M. B., Cechinel Filho V., 2012. Aleurites moluccana and its main active ingredient, the flavonoid 2"-O-rhamnosylswertisin, have promising antinociceptive effects in experimental models of hypersensitivity in mice. Pharmacology, Biochemistry and Behavior. 102, 302311. 
Quintão N. L. M., Rocha L. W., Silva G. F., Reichert S., Claudino V. D., Lucinda-Silva R. M., Malheiros A., De Souza M. M., Cechinel Filho V., Bresolin T. M. B., da Silva Machado M., Wagner T. M., Meyre-Silva C. 2014. Contribution of ??,-amyrenone to the anti-inflammatory and antihypersensitivity effects of Aleurites moluccana (L.) Willd. BioMed Research International.

Rageau J., 1973. Les plantes médicinales de la Nouvelle Calédonie. Travaux et Documents de I'ORSTOM, 23. Paris, $139 \mathrm{p}$.

Raharivelomanana P., Ansel J-L., Lupo E., Mijouin L., Guillot S., Butaud J-F., Ho R., Lecellier G., Pichon C., 2018. Tamanu oil and skin active properties : from traditional to modern cosmetic uses. Oilseeds \& fats Crops and Lipids. 25, D504.

Ramamoorthy P. K., Bono A., 2007. Antioxidant activity, total phenolic and flavonoid content of Morinda citrifolia fruit extracts from various extraction processes. Journal of Engineering Science and Technology. $2,70-80$.

Roberts W. E., Jiang L. I., Herndon J. H. Jr, 2015. Facial primer provides immediate and long-term improvements in mild-to-moderate facial hyperpigmentation and fine lines associated with photoaging. Clinical, Cosmetic and Investigational Dermatology. 8, 471-477.

Rybalko K. S., Konovalova O. A., Petrova E. F., 1976. Orientin-a new sesquiterpene lactone from Siegesbeckia orientalis. Khimiya Prirodnykh Soedinenii. 3, 394-395.

Saludes J.P., Garson M. J., Franzblau S. G., Aguinaldo A. M., 2002. Antitubercular constituents from the hexane fraction of Morinda citrifolia Linn. (Rubiaceae). Phytotherapy Research. 16, 683-685.

Sang S., Cheng X., Zhu N., Stark R. E., Badmaev V., Ghai G., Rosen R. T., Ho C-T., 2001. Flavonol glycosides and novel iridoid glycoside from the leaves of Morinda citrifolia. Journal of Agriculture and Food Chemistry. 49, 4478-4481.

Sennett, R., Rendl, M., 2012. Mesenchymal-epithelial interactions during hair follicle morphogenesis and cycling. Seminars in Cell \& Developmental Biology 23, 917-927.

Shamsuddin T., Rahman W., Khan S. A., Shamsuddin K. M., Kintzinger J. P., 1988. Moluccanin, a coumarinolignoid from Aleurites moluccana. Phytochemistry. 27, 1908-1909.

Sharath R., Harish B. G., Krishna V., Sathyanarayana B. N., Swamy H. M. K., 2010. Wound healing and protease inhibition activity of bacoside-a isolated from Bacopa monnieri Wettest. Phytotherapy Research. 24, 1217-1222.

Siddique, B.M., Ahmad, A., Alkarkhi, A.F.M., Ibrahim, M.H., Omar A.K, M., 2011. Chemical Composition and Antioxidant Properties of Candlenut Oil Extracted by Supercritical CO2. Journal of Food Science 76, C535C542.

Sivaramakrishna C., Rao C. V., Trimurtulu G., Vanisree M., Subbaraju G. V., 2005. Triterpenoid glycosides from Bacopa monnieri. Phytochemistry 66, 2719-2728.

Suciati, Lambert, L.K., Ross, B.P., Deseo, M.A., Garson, M.J., 2011. Phytochemical Study of Fagraea spp. Uncovers a New Terpene Alkaloid with Anti-Inflammatory Properties. Australian Journal of Chemistry 64, $489-494$. 
Sun H-X., Wang H., 2006. Immunosuppressive activity of the ethanol extract of Siegesbeckia orientalis on the immune responses to ovalbumin in mice. Chemistry \& Biodiversity. 3, 754- 761.

Tobin, D.J., 2017. Introduction to skin aging. Journal of Tissue Viability 26, 37-46.

Tsai, S.-C., Liang, Y.-H., Chiang, J.-H., Liu, F.-C., Lin, W.-H., Chang, S.-J., Lin, W.-Y., Wu, C.-H., Weng, J.-R., 2012. Anti-inflammatory effects of Calophyllum inophyllum L. in RAW264.7 cells. Oncology Reports 28, 10961102.

Vasavi H. S., Arun A. B., Rekha P-D., 2015. Anti-quorum sensing potential of Adenanthera pavonina. Pharmacognosy Research. 7, $105-109$.

Wang M., Kikuzaki H., Csiszar K., Boyd C. D., A., Fong S. F. T., Ghai G., Rosen R. T., Nakatani N., Ho C-T., 1999. Novel trisaccharide fatty acid ester identified from the fruits of Morinda citrifolia (Noni). Journal of Agriculture and Food Chemistry. 47, 4880-4882.

Wang M., Kikuzaki H., Jin Y., Nakatani N., Zhu N., Csiszar K., Boyd C., Rosen R. T., Ghai G.,Ho C-T., 2000. Novel glycosides from Noni (Morinda citrifolia). Journal of Natural Products. 63, $1182-1183$.

Wang F., Cheng X-L., Li Y-J., Shi S., Liu J-K., 2009. ent-Pimarane diterpenoids from Siegesbeckia orientalis and structure revision of a related compound. Journal of Natural Products. 72, 2005-2008.

Wang J., Zhou Y., Ye Y., Shang X., Cai Y., Xiong C., Wu Y., Xu H-X., 2011. Topical anti-inflammatory and analgesic activity of kirenol isolated from Siegesbeckia orientalis. Journal of Ethnopharmacology. 137, 1089- 1094.

Wang J., Zhou Y., Zhang Y., 2012. Kirenol production in hairy root culture of Siegesbeckea orientalis and its antimicrobial activity. Pharmacognosy Magazine. 8, 149-155.

Whistler A. W., 1985. Traditional and herbal medicine in the Cook Islands. Journal of Ethnopharmacology. 13, 239-280.

Whistler, W.A., 1988. Ethnobotany of Tokelau: The plants, their Tokelau names, and their uses. Economic Botany 42, 155-176.

Whistler, W.A., 1990. The other Polynesian gourd. Pacific Science, 44, 115-122.

Whistler, W.A., 1991. The ethnobotany of Tongan plants, their Tongan names and their uses. Honolulu, Hawaii: Bishop Museum Bulletin Botany 2. Bishop Museum Press.

Whistler, W. A., 1992. Polynesian herbal medicine. Lawai, Kauai, Hawaii: National Tropical Botanical Garden. Whistler, W.A., 2000. Plants in Samoan culture: The ethnobotany of Samoa. Honolulu, Hawaii: Isle Botanica.

Whistler A. W., 2009. Plants of the canoe people: an ethnobotanical voyage through Polynesia. National Tropical Botanical Garden: Kaua'i, Hawai'i, 241 p.

World Health Organization (WHO). Regional Office for the Western Pacific., 1998. Medicinal plants in the South Pacific: information on 102 commonly used medicinal plants in the South Pacific. Manila, Philippines: WHO Regional Office for the Western Pacific.

Wickramaratne Nirmali M., Punchihewa J. C., Wickramaratne D. B. M., 2016. In-vitro alpha amylase inhibitory activity of the leaf extracts of Adenanthera pavonina. BMC Complementary and Alternative Medicine. 16, DOI: 10.1186/s12906-016-1452-y.

Woo, H., Lee, S., Kim, S., Park, D., Jung, E., 2017. Effect of sinapic acid on hair growth promoting in human hair follicle dermal papilla cells via Akt activation. Archives of Dermatological Research 309, 381-388. 
Xiang Y., Zhang H., Fan C-Q., Yue J-M., 2004. Novel diterpenoids and diterpenoid glycosides from Siegesbeckia orientalis. Journal of Natural Products. 67, 1517-1521.

Xiang Y., Fan C-Q., Yue J-M., 2005. Novel sesquiterpenoids from Siegesbeckia orientalis. Helvetica Chimica Acta. $88,160-170$.

Xiong J., Ma Y., Xu Y., 1997. The constituents of Sigesbeckia orientalis. Natural Product Sciences. 3, 14-18.

Yadav N., Misra G. Nigam S. K., 1976. Triterpenoids of Adenanthera pavonina bark. Planta Medica. 29, 176 178.

Yamaguchi Y., Hearing V. J., 2009. Physiological factors that regulate skin pigmentation. BioFactors. 35, 193199.

Yamaguchi Y., Morita A., Maeda A., Hearing V. J., 2016. Regulation of skin pigmentation and thickness by Dickkopf 1 (DKK1). Journal of Investigative Dermatology Symposium Proceedings. 14, 73 - 75.

Yatagai, T., Shimauchi, T., Yamaguchi, H., Sakabe, J., Aoshima, M., Ikeya, S., Tatsuno, K., Fujiyama, T., Ito, T., Ojima, T., Tokura, Y., 2018. Sensitive skin is highly frequent in extrinsic atopic dermatitis and correlates with disease severity markers but not necessarily with skin barrier impairment. Journal of Dermatological Science 89, 33-39.

Yokosuka, A., Suzuki, T., Mimaki, Y., 2012. New cholestane glycosides from the leaves of Cordyline terminalis. Chemical \& Pharmaceutical Bulletin. 60, 275-279.

Yoshida, N., Kanekura, T., Higashi, Y., Kanzaki, T., 2006. Bidens pilosa suppresses interleukin-1ß-induced cyclooxygenase-2 expression through the inhibition of mitogen activated protein kinases phosphorylation in normal human dermal fibroblasts. The Journal of Dermatology 33, 676-683.

Younos C., Rolland A., Fleurentin J., Lanhers M-C., Misslin R., Mortier F., 1990. Analgesic and Behavioural effects of Morinda citrifolia. Planta Medica. 56, 430-434.

Zakaria, M.B., Vijayasekaran, Ilham, Z., Muhamad, N.A., 2014. Anti-inflammatory activity of Calophyllum Inophyllum fruits extracts. Procedia Chemistry 13, 218-220.

Zdero C., Bohlmann F., King R. M., Robinson H., 1991. Sesquiterpene lactones and other constituents from Siegesbeckia orientalis and Guizotia scabra. Phytochemistry. 30, 1579-1584.

Zepernick B., 1972. Arzneipflanzen dor Polynesier. Berlin, Germany: Verlag von Dietrich Reimer.

Zhao, P., Sui, B.-D., Liu, N., Lv, Y.-J., Zheng, C.-X., Lu, Y.-B., Huang, W.-T., Zhou, C.-H., Chen, J., Pang, D.-L., Fei, D.D., Xuan, K., Hu, C.-H., Jin, Y., 2017. Anti-aging pharmacology in cutaneous wound healing: effects of metformin, resveratrol, and rapamycin by local application. Aging Cell 16, 1083-1093.

Zhou Y., Shen Y.-H., Zhang C., W.-D. Zhang W.-D., 2007. Chemical constituents of Bacopa monnieri. Chemistry of Natural Compounds. 43, $355-357$.

Zillich, O.V., Schweiggert-Weisz, U., Eisner, P., Kerscher, M., 2015. Polyphenols as active ingredients for cosmetic products. International Journal of Cosmetic Science 37, 455-464.

Zin Mohd Z., Abdul-Hamid A., Osman A., 2002. Antioxidative activity of extracts from Mengkudu (Morinda citrifolia L.) root, fruit and leaf. Food Chemistry 78, 227-231. 
Zollo P. H. A., Kuiaté J. R., Menut C., Lamaty G., Bessière J. M., Chalchat J. C., Garry R. Ph., 1995. Aromatic Plants of Tropical Central Africa. Part XX. The Occurrence of 1-Phenylhepta-1,3,5-triyne the essential oil of Bidens pilosa L. from Cameroon. Flavour and Fragrance Journal. 10, 97-10.

Zulueta C. A., Tada M., Ragasa C. Y., 1995. A diterpene from Bidens pilosa. Phytochemistry. 38, 1449-1450. 
